\title{
Small-scale heterogeneity of microbial N uptake in streams and its implications at the ecosystem level
}

\author{
Marc Peipoch,,${ }^{1,3}$ Esperança Gacia,,${ }^{1}$ Elliot Bastias, ${ }^{1}$ Alexandra Serra,,${ }^{1}$ Lorenzo Proia, ${ }^{2}$ Miquel Ribot, ${ }^{1}$ \\ Stephanie N. Merbt, ${ }^{1}$ And Eugènia Martí ${ }^{1}$ \\ ${ }^{1}$ Integrative Freshwater Ecology Group, Center for Advanced Studies of Blanes (CEAB-CSIC), Blanes, 17300, Spain \\ ${ }^{2}$ Catalan Institute for Water Research, Scientific and Technological Park of the University of Girona, Girona, 17003, Spain
}

\begin{abstract}
Large-scale factors associated with the environmental context of streams can explain a notable amount of variability in patterns of stream $\mathrm{N}$ cycling at the reach scale. However, when environmental factors fail to accurately predict stream responses at the reach level, focusing on emergent properties from small-scale heterogeneity in $\mathrm{N}$ cycling rates may help understand observed patterns in stream $\mathrm{N}$ cycling. To address how smallscale heterogeneity may contribute to shape patterns in whole-reach $\mathrm{N}$ uptake, we examined the drivers and variation in microbial $\mathrm{N}$ uptake at small spatial scales in two stream reaches with different environmental constraints (i.e., riparian canopy). Our experimental design was based on two ${ }^{15} \mathrm{~N}$ additions combined with a hierarchical sampling design from reach to microhabitat scales. Regardless of the degree of canopy cover, small-scale heterogeneity of microbial $\mathrm{N}$ uptake ranged by three orders of magnitude, and was characterized by a low abundance of highly active microhabitats (i.e., hot spots). The presence of those hot spots of $\mathrm{N}$ uptake resulted in a nonlinear spatial distribution of microbial $\mathrm{N}$ uptake rates within the streambed, especially in the case of epilithon assemblages. Small-scale heterogeneity in $\mathrm{N}$ uptake and turnover rates at the microhabitat scale was primarily driven by power relationships between $\mathrm{N}$ cycling rates and stream water velocity. Overall, fine benthic organic matter (FBOM) assemblages responded clearly to changes in the degree of canopy cover, overwhelming small-scale heterogeneity in its $\mathrm{N}$ uptake rates, and suggesting that FBOM contribution to whole-reach $\mathrm{N}$ uptake was principally imposed by environmental constraints from larger scales. In contrast, $\mathrm{N}$ uptake rates by epilithon showed no significant response to different environmental influences, but identical local drivers and spatial variation in each study reach. Therefore, contribution of epilithon assemblages to whole-reach $\mathrm{N}$ uptake was mainly associated with emerging properties from small-scale heterogeneity at lower spatial scales.
\end{abstract}

Key words: streams, nitrogen, heterogeneity, emergent properties, cross-scale interactions.

\section{INTRODUCTION}

Streams are exceptionally dynamic and complex systems due to their unique combination of geomorphic heterogeneity and hydrological connectivity across different spatial and temporal scales (Ward 1989). Spatial heterogeneity in stream ecosystems has been historically organized in a set of hierarchical levels from small (e.g., microhabitats and habitats) to larger scales such as reaches, segments, and catchments (Frissell et al. 1986). With this hierarchical perspective, the relationship between pattern and process across different hierarchical levels has been advised as an organizing driver of stream ecosystems (Fisher et al. 1998, Poole 2002). Most of this previous research is based on the hierarchical principle that mechanisms operate at different scales than those

Manuscript received 30 June 2015; revised 24 November 2015; accepted 1 December 2015. Corresponding Editor: S. D. Allison.

${ }^{3}$ Present address: Division of Biological Sciences, University of Montana, Missoula, Montana 59812, USA.

E-mail: marc.peipoch@mso.umt.edu on which patterns are observed (O'Neill et al. 1986). In some cases, patterns are seen to be imposed by larger scale constraints while, in other cases, observed patterns are rather emerging from interactions among lower-level units of the system (Levin 1992). However, in both scenarios, the role of cross-scale interactions as critical drivers of ecosystem dynamics and behavior is implicitly recognized.

In reality, the relative importance of large-scale constraints and emerging properties can vary across space (Sponseller and Fisher 2006) and over time (King et al. 2004). Cross-scale interactions are essentially originated from changes in environmental drivers of ecosystems which can directly change patterns at large scales and overwhelm heterogeneity at lower hierarchical levels or, in contrast, alter local controls at small scales and change patterns observed at larger scales (Peters et al. 2007). For many structural and functional attributes of stream ecosystems, it is not well known to what extent patterns at a particular scale are imposed by large-scale influences from the environmental context or emerging as the overall effect of spatial heterogeneity at smaller scales. 
This is a central ecological question in streams and in practically any other ecosystem (Thompson et al. 2001, Turner and Chapin 2005), the answer of which is necessary to further understand the causes and consequences of ecosystem patterns and how do they change across scales (Levin 1992).

Nitrogen $(\mathrm{N})$ cycling is one of the central ecological processes in streams for which most of the research has been hitherto focused at the reach scale (hundreds of meters), since this is the spatial unit at which nutrient spiraling metrics are typically quantified (Newbold et al. 1981). Research at this scale has provided solid evidences on how patterns of whole-reach $\mathrm{N}$ uptake in stream ecosystems are directly influenced by environmental constraints at similar or larger scales such as canopy cover (Valett et al. 2008), land uses (von Schiller et al. 2009), or discharge (Peterson et al. 2001). At the same time, however, difficulties are frequently encountered when relating patterns in stream $\mathrm{N}$ uptake to environmental variation at the reach scale (e.g., Webster et al. 2003); while in other cases and despite the numerous controlling factors considered, total variance in $\mathrm{N}$ processing rates is still far from being fully explained (O'Brien et al. 2007, Mulholland et al. 2008). Together, those results provide evidence that functional relationships between environmental drivers and $\mathrm{N}$ cycling at the reach scale ought to be complemented with further investigation on how small-scale heterogeneity in $\mathrm{N}$ processes contribute to patterns of whole-reach $\mathrm{N}$ uptake.

Patterns of $\mathrm{N}$ uptake in stream ecosystems are mostly driven by microbial compartments living in the stream benthos, although in some cases other benthic compartments (e.g., filamentous algae, bryophytes, or macrophytes) can substantially contribute to stream N cycling (Grimm 1987, von Schiller et al. 2009). Microbial assemblages are ubiquitous in streams benthos, but with a large plasticity in their composition, distribution, and trophic levels. Complex biofilm structures developing above mineral substrata (here referred to as epilithon) are principally composed by a mixture of algae, normally dominated by diatoms (Sheath and Cole 1992), and bacteria (Lock 1993) embedded in a mucopolisacharide matrix. On the other hand, fine benthic organic matter (here referred to as FBOM) accumulated in depositional zones of the stream channel hosts microbial communities mostly dominated by heterotrophic bacteria in close association with detritus (Findlay et al. 2002).

As predicted by hierarchy theory (O'Neill et al. 1986), environmental constraints associated with each stream are initially set at the catchment scale and then translated to smaller hierarchical levels (i.e., reach, habitat, and microhabitat) determining the relative abundance, community composition, and potential $\mathrm{N}$ demand of microbial compartments (Fig. 1). For instance, the quantity and quality of allocthonous litter inputs determine the relative abundance and nutrient demand of FBOM (Bonin et al. 2000). While differences in light incidence can significantly increase the relative abundance of algae in epilithon (Sabater et al. 2000) and ultimately its N demand (Marti and Sabater 1996). Our knowledge on how environmental features at large spatial scales influence microbes' contribution to stream $\mathrm{N}$ uptake contrasts with fewer studies addressing controlling factors of $\mathrm{N}$ uptake below the reach scale and its inherent small-scale heterogeneity (but see Baker et al. 2009). Spatial heterogeneity at small spatial scales is

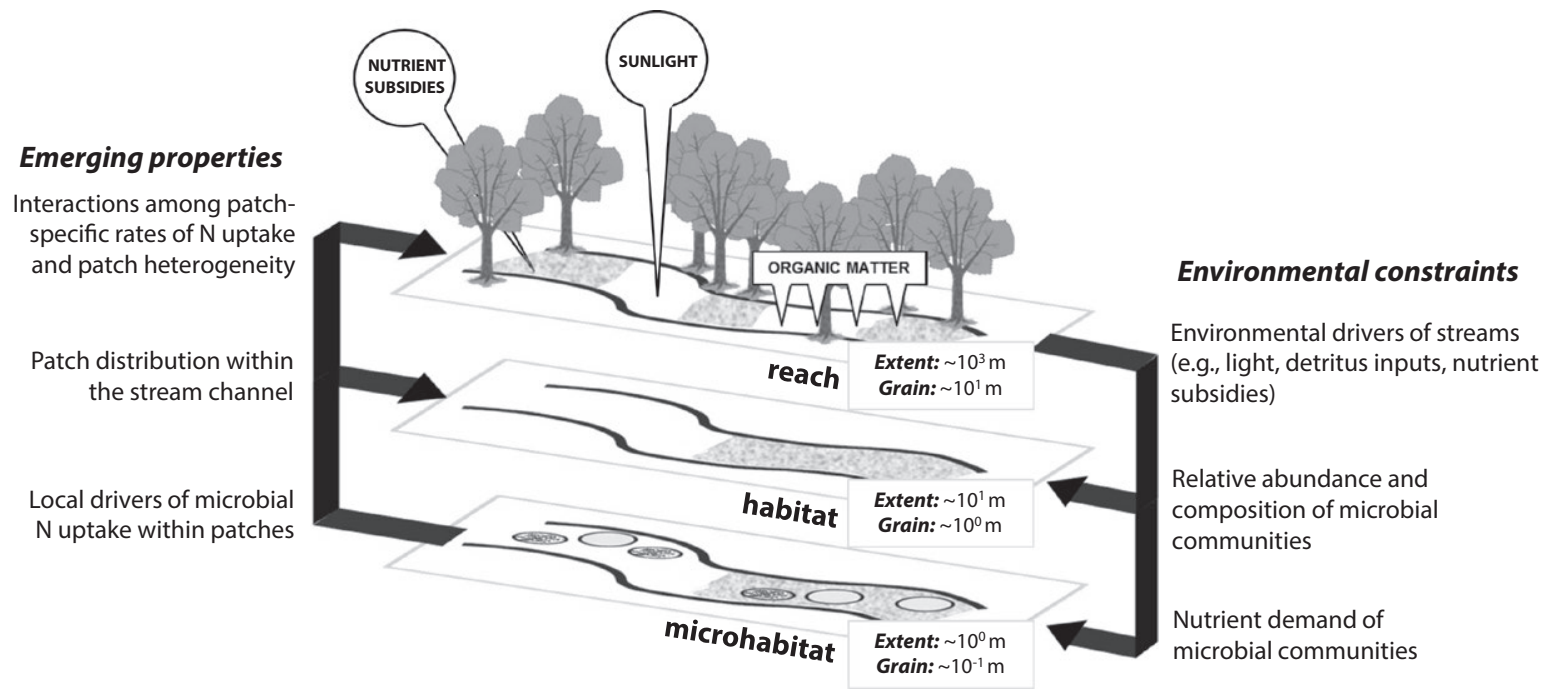

FIG. 1. Conceptual scheme of this study illustrating the three hierarchical spatial scales considered: reach, habitat, and microhabitat. The grain and extent associated with each scale is indicated in the figure. Arrows on the right represent cross-scale interactions originated from changes in environmental drivers of each stream at the reach scale that determine the relative abundance, composition, and potential $\mathrm{N}$ demand of microbial compartments at habitat and microhabitat scales. Arrows on the left represent emerging properties at the reach scale resulting from the interactions among patch-specific drivers of microbial $\mathrm{N}$ uptake and the heterogeneity of these patches at the habitat and microhabitat levels . 
inevitably aggregated at larger scales, and thus must influence functional relationships between environmental drivers and $\mathrm{N}$ cycling typically quantified at the reach scale. Here, cross-scale interactions from small to larger scales are defined as emergent properties, which refer to the overall set of complex interactions among the controlling factors of $\mathrm{N}$ uptake at small scales, the patchspecific rates of $\mathrm{N}$ uptake, and the heterogeneity of these patches at low levels of stream organization (Fig. 1).

In this study, we examined patterns and heterogeneity in microbial $\mathrm{N}$ uptake at small spatial scales in two stream reaches with different environmental constraints (i.e., riparian canopy), and discussed how environmental constraints and emergent properties from small-scale heterogeneity in microbial $\mathrm{N}$ dynamics contribute to dictate $\mathrm{N}$ uptake patterns at the whole-reach scale. Our experimental design was based on two ${ }^{15} \mathrm{~N}$ additions with a detailed hierarchical design and a spatially explicit analysis in order to determine the relative importance of environmental constraints and small-scale heterogeneity in patterns of stream $\mathrm{N}$ uptake.

\section{STUdy Site}

Fuirosos is a third-order stream draining a forested catchment of $16.2 \mathrm{~km}^{2}$. It is located in the MontnegreCorredor Natural Park (Barcelona, northeast Spain), a mountain range with climate typical from the Mediterranean region. Basal flow discharge ranges between 0 and $25 \mathrm{~L} / \mathrm{s}$, but discharge can increase up to $500 \mathrm{~L} / \mathrm{s}$ during storms (Butturini et al. 2008, Vazquez et al. 2013).

Two reaches differing in the density of riparian vegetation were defined in Fuirosos: a shaded reach (SR) of $315 \mathrm{~m}$, with a dense canopy cover mainly made up of sycamore (Platanus $\times$ hispanica), alder (Alnus glutinosa), and hazel (Corylus avellana); and an open reach (OR) of $360 \mathrm{~m}$, where selective harvesting of riparian tree species have considerably reduced canopy cover. Physicochemical characteristics of $\mathrm{OR}$ and $\mathrm{SR}$ are summarized in Appendix S1. Essentially, OR showed lower leaf area index, higher irradiance, and higher concentrations of soluble reactive phosphorus than the SR (Appendix S1).

\section{Methods}

\section{Experimental design}

Our hierarchical sampling design consisted of two reaches, six habitats, five microhabitats for each microbial compartment. At each study reach, we defined a total of eight to nine sampling locations along the entire reach, hereafter referred to as reach stations. Within reach stations 1 and 4, we defined three sub-reaches (from reach station 1-2, 2-3, and 3-4) each of them composed by a riffle/pool sequence. Within each sub-reach, we selected one riffle and one pool habitat and sampled five microhabitats within each habitat. This hierarchical design resulted in a total of 60 microhabitats sampled per microbial compartment (i.e., epilithon and FBOM), 30 of them in each reach and habitat. In order to estimate $\mathrm{N}$ uptake and turnover of microbial compartments across whole-reach, habitat, and microhabitat scales, we conducted a ${ }^{15} \mathrm{~N}$ addition at the OR on 5 May 2012 and another $2 \mathrm{~d}$ later at the SR. Samples for stream water and benthic compartments collected at each reach station were used to estimate the relative contribution of microbial compartments to whole-reach $\mathrm{N}$ uptake compared to other benthic compartments by following procedures from Mulholland et al. (2000) and von Schiller et al. (2009). Samples collected at each microhabitat patch were used to characterize the spatial heterogeneity in $\mathrm{N}$ cycling of epilithon and FBOM at the microhabitat and habitat scale.

\section{${ }^{15} \mathrm{~N}$ additions}

At each study reach, we conducted a 24-h constant rate addition of ${ }^{15} \mathrm{~N}-\mathrm{NH}_{4}^{+}$(as $99 \%$ enriched ${ }^{15} \mathrm{NH}_{4} \mathrm{Cl}$ ). The ${ }^{15} \mathrm{NH}_{4} \mathrm{Cl}$ additions were designed to produce a 10,000 fold increase in the ${ }^{15} \mathrm{~N}:{ }^{14} \mathrm{~N}$ ratio of stream water $\mathrm{N}-\mathrm{NH}_{4}^{+}$, which elevated ambient $\mathrm{N}-\mathrm{NH}_{4}^{+}$concentration by $6 \%$ and $5 \%$ at the OR and SR, respectively. Before (i.e., background sampling), after $\sim 24 \mathrm{~h}$ of the beginning of the ${ }^{15} \mathrm{~N}-\mathrm{NH}_{4}^{+}$addition (i.e., plateau sampling), and $\sim 14 \mathrm{~h}$ after the end of the addition (i.e., post-addition sampling) we collected water samples for nutrient chemistry and isotopic ${ }^{15} \mathrm{~N}$ signal each reach station. All water samples were immediately filtered through ashed Albet (Barcelona, Spain) glass fiber filters $(0.7 \mu \mathrm{m}$ pore size $)$. Filtered samples for nutrient chemistry $(15 \mathrm{~mL}$, two replicates per reach station) were stored on ice in the field, and then stored at $-20^{\circ} \mathrm{C}$ in the laboratory until analysis. Samples for ${ }^{15} \mathrm{~N}-\mathrm{NH}_{4}^{+}$(4 $\mathrm{L}$, one replicate per reach station) were immediately processed as explained in the laboratory methods section, while samples for ${ }^{15} \mathrm{~N}-\mathrm{NO}_{3}^{-}(1 \mathrm{~L}$, one replicate per reach station) were kept frozen until further analysis. Two days after each ${ }^{15} \mathrm{~N}-\mathrm{NH}_{4}^{+}$addition, a constant rate addition of $\mathrm{NaCl}$ (used as a conservative tracer) was conducted to characterize the hydrology of each reach. During this addition, conductivity was automatically recorded at the first and last reach stations along the reaches every $10 \mathrm{~s}$ using WTW (Weilheim, Germany) 3110 conductivity meters. Additionally, at plateau conditions we measured conductivity at all reach stations to assess the dilution from lateral inflow along the reach.

\section{Characterization of canopy cover and benthic compartments at the whole-reach scale}

Leaf area index (LAI) was estimated in and out of the stream-riparian corridor during the addition using a Sunfleck PAR ceptometer (ICT international, Australia, Armidale, New South Wales, Australia). Water temperature and PAR were recorded in each reach station and habitat at 20-min intervals during two weeks using 
waterproof temperature and light data loggers (HOBO Pendant UA-002-64, ONSET, Bourne, Massachusetts, USA). Prior to the ${ }^{15} \mathrm{~N}$ release, we determined the wetted width, the relative distribution of riffles and pools, and the percent cover of streambed substrates (fine sediments as FBOM; and pebbles, cobbles, boulders, and bedrock as epilithon) at $5 \mathrm{~m}$ intervals along the reach. The percent cover of filamentous algae, bryophytes, and macrophytes was estimated by determining their presence/absence every $10 \mathrm{~cm}$ along each transect at $5 \mathrm{~m}$ intervals along the reach. Reach-weighted standing stocks of each benthic compartments were calculated using relative cover estimations and patch-specific measures of dry mass and ash free dry mass (AFDM) at each reach station $(n=9-10)$. Patch-specific biomass of epilithon and FBOM was quantified following procedures from von Schiller et al. (2009). Coarse benthic organic matter (CBOM) was sampled by collecting all organic matter found within a $104 \mathrm{~cm}^{2}$ area. Suspended particulate organic matter (SPOM) was sampled by filtering 2-6 L of stream water through preweighted FVF glass fiber filters. Filamentous algae, bryophytes, and macrophytes were sampled by scraping all material from a known area covered by each compartment. All samples were dried at $60^{\circ} \mathrm{C}$ until constant weight and further processed for elemental content ( $\mathrm{C}$ and $\mathrm{N}$ ), and ${ }^{15} \mathrm{~N}$ and ${ }^{13} \mathrm{C}$ analysis (see Laboratory methods). To estimate the relative contribution of each compartment to whole-reach $\mathrm{N}$ uptake we collected ${ }^{15} \mathrm{~N}$ composite samples $(n=3-5)$ during the ${ }^{15} \mathrm{~N}$ plateau for each compartment and at each reach station following the methods described for biomass samples.

\section{Characterization of the microhabitat patches}

Prior to each ${ }^{15} \mathrm{~N}-\mathrm{NH}_{4}^{+}$addition, a total of 30 microhabitat patches for epilithon and FBOM were randomly sampled following a stratified sampling design of five microhabitat samples per riffle and pool within each subreach. The location of each microhabitat was recorded based on the nearest reach station. Microhabitat boundaries were defined as one or two cobbles (depending on size) for epilithon and an area of $\sim 15 \mathrm{~cm}$ diameter for FBOM. Before epilithon and FBOM samplings, we measured water depth and velocity using a velocity meter (Schiltknecht, Messtechnik, Gossau, Zurich, Switzerland) at each microhabitat, and quantified the relative abundance of green algae, cyanobacteria, and diatoms of these compartments using a BenthoTorch (bbe, Germany, Schwentinental, Germany) portable fluorometer probe. After these measurements, samples of epilithon and FBOM were collected and processed for AFDM, C and $\mathrm{N}$ elemental content, and ${ }^{15} \mathrm{~N}$ and ${ }^{13} \mathrm{C}$ analysis. At each microhabitat, we also collected two subsamples of epilithon and FBOM for analysis of extracellular enzymatic activities (EEA, $4 \mathrm{~mL}$ ) and one subsample of epilithon for analysis of extracellular polymeric substances (EPS, $10 \mathrm{~mL}$ ). These samples were stored on ice in the field, and then refrigerated at $4^{\circ} \mathrm{C}$ and stored at $-20^{\circ} \mathrm{C}$ in the laboratory until further processing and analysis (see Laboratory methods). At the ${ }^{15} \mathrm{~N}$ plateau sampling, we collected samples of epilithon and FBOM for the ${ }^{15} \mathrm{~N}$ analysis (30 per compartment and reach) at the same locations where background samples had been collected in order to estimate patch-specific $\mathrm{NH}_{4}^{+}$uptake rates at each microhabitat.

\section{Laboratory methods}

Stream water samples were analyzed for ammonium $\left(\mathrm{N}-\mathrm{NH}_{4}^{+}\right)$, nitrate $\left(\mathrm{N}-\mathrm{NO}_{3}^{-}\right)$and SRP concentrations following standard colorimetric methods (APHA 1995) on an Automatic Continuous Flow FUTURA-ALLIANCE Analyzer at the CEAB-CSIC Biogeochemistry laboratory. The ${ }^{15} \mathrm{~N}$ content of stream water $\mathrm{NH}_{4}^{+}$and $\mathrm{NO}_{3}^{-}$ was determined following the ammonia diffusing procedure adapted from Holmes et al. (1998) and Sigman et al. (1997), respectively. To measure ${ }^{15} \mathrm{~N}-\mathrm{NO}_{3}^{-}$signatures we amended a known volume of sample with $3 \mathrm{~g}$ of $\mathrm{MgO}$ and $5 \mathrm{~g}$ of $\mathrm{NaCl}$ and boiled it to remove any $\mathrm{NH}_{4}^{+}$. We then added $0.5 \mathrm{mg} \mathrm{MgO}$ and $0.5 \mathrm{mg}$ Devarda's alloy to reduce the $\mathrm{NO}_{3}^{-}$to $\mathrm{NH}_{4}^{+}$, and treated the remaining sample as for ${ }^{15} \mathrm{~N}-\mathrm{NH}_{4}^{+}$analysis. To measure ${ }^{15} \mathrm{~N}-\mathrm{NH}_{4}^{+}$, we amended a known volume of sample with $3 \mathrm{~g} / \mathrm{L}$ of $\mathrm{MgO}$ and $50 \mathrm{~g} / \mathrm{L}$ of $\mathrm{NaCl}$ and a Teflon filter packet containing a $1-\mathrm{cm}$-diameter combusted Whatman GF/D fiber glass filter acidified with $25 \mathrm{~mL}$ of $2.5 \mathrm{~mol} / \mathrm{L}$ $\mathrm{KHSO}_{4}$ (to trap the volatilized $\mathrm{NH}_{3}$ ), and incubated it on a shaker at $40^{\circ} \mathrm{C}$ for 4 weeks. Once the incubation was completed, we removed the filter packets and placed them in a desiccator for $4 \mathrm{~d}$. We encapsulated filters in tins and stored them until ${ }^{15} \mathrm{~N}$ analysis.

Biomass samples of all benthic compartments were oven-dried at $60^{\circ} \mathrm{C}$ for $72 \mathrm{~h}$, weighed on a Sartorius (Goettingen, Germany) MC1 analytical balance, combusted at $500^{\circ} \mathrm{C}$ for $5-6 \mathrm{~h}$, and reweighed for calculation of dry mass and AFDM. Biomass samples for elemental and isotopic analyses of $\mathrm{C}$ and $\mathrm{N}$ were ground, thoroughly homogenized, weighed to the nearest $0.001 \mathrm{mg}$ on a Mettler-Toledo (Greifensee, Germany) MX5 microbalance, encapsulated in tins, and sent to the UC Davis Stable Isotope Facility (California, USA). The C and N content (as a percentage of total dry mass) and their stable isotope signatures were determined using a PDZ Europa ANCA-GSL elemental analyzer interfaced to a PDZ Europa 20-20 isotope ratio mass spectrometer (Sercon, Cheshire, UK). All ${ }^{15} \mathrm{~N}$ and ${ }^{13} \mathrm{C}$ signatures are expressed in terms of delta values $\left(\delta^{15} \mathrm{~N}\right.$ and $\left.\delta^{13} \mathrm{C}\right)$, which are parts per thousand (\%o) differences from a standard.

The extracellular activities of the enzymes leucineaminopeptidase (EC 3.4.11.1) and $\beta$-D-1, 4-glucosidase (EC 3.2.1.21) in the epilithon and FBOM were measured spectrofluorometrically (UV-2401PC, ultraviolet-visible spectrometer; Shimadzu, Columbia, Maryland, USA) $24 \mathrm{~h}$ after collection, by using the fluorescent-linked substrates L-leucine-4-methyl-7-coumarinylamide(Leu-AMC; Sigma-Aldrich, Madrid, Spain) and 4-methylumbelliferyl 
$\beta$-D-glucopyranoside (4-MUF $\beta$-D-glucoside; SigmaAldrich), as described by Proia et al. (2012). We used substrate concentrations of $0.3 \mathrm{mmol} / \mathrm{L}$ based on saturation curves performed previously for each compartment from the study stream.

The extraction of EPS from the epilithon was performed using a cation exchange resin (Dowex Marathon C, Na-form, strongly acid; Sigma-Aldrich) following the procedure described in Romani et al. (2008) and Ylla et al. (2010). The polysaccharide content in the EPS fraction was measured by the phenol-sulfuric acid assay (Dubois et al. 1956). Standards of glucose $(0-200 \mu \mathrm{g} / \mathrm{mL})$ were also run with the set of samples.

\section{Parameter calculations}

Calculations of $\mathrm{NH}_{4}^{+}$uptake length $\left(\mathrm{NH}_{4}^{+}-S_{\mathrm{w}} ; \mathrm{m}\right)$ and ${ }^{15} \mathrm{~N}$ storage in the reach were done following methods described by Mulholland et al. (2000). In brief, $\mathrm{NH}_{4}^{+}-S_{\mathrm{w}}$ was calculated as the inverse of the slope of the regression between natural logarithm of ${ }^{15} \mathrm{~N}-\mathrm{NH}_{4}^{+}$tracer and distance downstream, while ${ }^{15} \mathrm{~N}$ storage was calculated by integrating the decline in ${ }^{15} \mathrm{~N}$ tracer of each benthic compartment over distance. $\mathrm{NH}_{4}^{+}-S_{\mathrm{w}}$ was then used to estimate uptake velocity $\left(\mathrm{NH}_{4}^{+}-V_{\mathrm{f}} ; \mathrm{m} / \mathrm{min}\right)$ and areal $\mathrm{NH}_{4}^{+}$ uptake rate $\left(\mathrm{NH}_{4}^{+}-U ; \mathrm{mg} \mathrm{N} \cdot \mathrm{m}^{-2} \cdot \mathrm{d}^{-1}\right)$ following equations described in (Webster and Valett 2006). Whole-reach rates of ${ }^{15} \mathrm{~N}-\mathrm{NH}_{4}^{+}$nitrification and regeneration of assimilated ${ }^{15} \mathrm{~N}_{-} \mathrm{NH}_{4}^{+}$were estimated from the longitudinal profiles in the reaches of ${ }^{15} \mathrm{~N}-\mathrm{NO}_{3}^{-}$and ${ }^{15} \mathrm{~N}-\mathrm{NH}_{4}^{+}$fluxes from water samples collected prior to the end of the addition and $14 \mathrm{~h}$ after the end of the ${ }^{15} \mathrm{~N}$ addition, respectively. Best fit was estimated using the Microsoft Excel 2010 Solver and following model procedures described by Mulholland et al. (2000).

Compartment-specific $\mathrm{NH}_{4}^{+}$uptake rates $\left(\mathrm{mg} \mathrm{N} \cdot \mathrm{m}^{-2} \cdot \mathrm{d}^{-1}\right)$ for each benthic compartment were calculated based on ${ }^{15} \mathrm{~N}$ data from the plateau sampling using the following equation:

$$
\begin{aligned}
\mathrm{NH}_{4}^{+} \text {uptake rate }= & \left(\left(\delta_{d}^{15} \mathrm{~N} / 1000\right) \times 0.003663\right. \\
& \left.\times \mathrm{N}_{\text {biomass }} / \delta_{d}^{15} \mathrm{NH}_{4}^{+}\right) / T
\end{aligned}
$$

where $\delta^{15} \mathrm{~N}$ are the plateau values of each compartment, $\mathrm{N}_{\text {biomass }}$ is $\mathrm{N}$ standing stock of each compartment (mg N/ $\left.\mathrm{m}^{2}\right), \delta^{15} \delta^{15} \mathrm{NH}_{4}^{+}$are stream water $\delta^{15} \mathrm{~N}-\mathrm{NH}_{4}^{+}$plateau values, and $T$ represents the elapsed time since the start of the ${ }^{15} \mathrm{~N}-\mathrm{NH}_{4}^{+}$addition $(24 \mathrm{~h})$. Compartment-specific $\mathrm{NH}_{4}^{+}$ uptake rates for epilithon and FBOM were calculated at both whole-reach and microhabitat scales. To calculate compartment-specific $\mathrm{NH}_{4}^{+}$uptake rates at whole-reach scale (i.e., data from each reach station) we used the reachweighted $\mathrm{N}_{\text {biomass }}$ of each compartment. The sum of wholereach $\mathrm{NH}_{4}^{+}$uptake rates for each compartment represents the total assimilatory $\mathrm{NH}_{4}^{+}$uptake rate at whole-reach scale. To calculate compartment-specific $\mathrm{NH}_{4}^{+}$uptake rates of epilithon and $\mathrm{FBOM}$ at the microhabitat scale (i.e., data from microhabitat samples) we used the patchspecific $\mathrm{N}_{\text {biomass }}$ of each microhabitat sample.

Nitrogen turnover rates (per day, $\mathrm{d}^{-1}$ ) for each benthic compartment at the whole-reach scale was calculated using the slope of the regression between ln-transformed $\delta^{15} \mathrm{~N}$ values from post-addition samples collected at the reach stations 1-3 and time after the end of the addition. Turnover rates of epilithon and FBOM at the microhabitat scale were estimated by dividing compartmentspecific $\mathrm{NH}_{4}^{+}$uptake rates $\left(\mathrm{mg} \mathrm{N} \cdot \mathrm{m}^{-2} \cdot \mathrm{d}^{-1}\right)$ by the patch-specific $\mathrm{N}_{\text {biomass }}$ of each sample.

\section{Statistical analysis}

Comparisons between the two study reaches for physical and chemical parameters characterizing each stream reach were done using separate Kruskal-Wallis nonparametric analysis of variance (ANOVA) using reach type as factor. Significant differences in the structure and function of epilithon and FBOM communities between the study reaches were examined performing a mixed-model nested ANOVA with reach as the fixed main factor, habitat as a random nested factor, and microhabitat providing replication within habitats ( $n=30$ per reach and compartment) using the aov function in stats package ( $R$ Core Team 2013) in $R$. Nested ANOVA analysis allowed the partition of variation in response variables among the three hierarchical levels considered in this study (reach, habitat, and microhabitat) while avoiding pseudo-replication when comparing reach averages. Estimations of the percent of variation associated with each spatial scale (reach, habitat, and microhabitat as the residual variation) for each of the structural and functional parameters considered in this study were performed using a variance component model (i.e., random model) with both reach and habitat (nested within reach) as random factors using the varcomp function in the package varComp (Long Qu 2015) in R. All variables included in those two linear models were previously log-transformed.

Spatial heterogeneity in $\mathrm{N}-\mathrm{NH}_{4}^{+}$uptake and turnover rates of microbial compartments at the microhabitat scale was examined by calculating the probability distribution for the data collected at each study reach. Because original data for uptake and turnover rates did not meet normality requirements, we used kernel density estimations (KDE, $n=30$ for each assemblage and reach, bandwidth $=0.1)$ to estimate the probability density function of uptake and turnover rates. Comparisons of uptake and turnover probability distributions among reaches were done using Kolmogorov-Smirnov tests in order to test whether the probability for uptake and turnover rates to take on a given value changed among the two study reaches. In addition, spatial heterogeneity in $\mathrm{N}-\mathrm{NH}_{4}^{+}$uptake of microbial compartments at the microhabitat scale was mapped using significant regressions between water depth and $\mathrm{NH}_{4}^{+}$uptake rates observed at each study reach, and cross-sectional profiles (every 
$20 \mathrm{~cm}$ ) of water depth every $20 \mathrm{~m}$ along the study reach. Regression estimations of $\mathrm{NH}_{4}^{+}$uptake rates by each reach were mapped in a three-dimensional plot $(x=$ reach length, $y=$ reach width, $z=\mathrm{NH}_{4}^{+}$uptake rate) to visualize estimated heterogeneity of $\mathrm{NH}_{4}^{+}$uptake rates of microbial compartments and its spatial distribution within each reach.

Relationships among structural features and $\mathrm{N}$ cycling rates in microbial compartments were evaluated using a linear mixed-effects (LME) model accounting for the random effects of the hierarchical design employed in our sampling, which included reach and habitat (nested within reach) as the random spatial effects and all measured structural parameters as fixed effects. All explanatory and response variables were log-transformed previously to the analysis. Selection of the best model was performed by minimizing AIC values after following an all subsets routine. A spherical autocorrelation structure (using microhabitat distance from the addition point) was also included to our model but it did not improve the LME model fit (i.e., reduced AIC) and it was therefore removed. Error structures were applied to normalize variance in the residuals due to heteroscedasticity observed at the habitat scale. LME models were fitted using restricted log-likelihood with the lme function in the package nlme (Pinheiro et al. 2015) in R. Further detail on the model is provided in Table 5.

Finally, we used linear correlations to compare total $\mathrm{NH}_{4}^{+}$uptake $\left(\mathrm{NH}_{4}^{+}-U\right)$ measured from the ${ }^{15} \mathrm{~N}^{-\mathrm{NH}_{4}^{+}}$decay in the water column vs. scaled up values of $\mathrm{NH}_{4}^{+}$assimilatory uptake rates in epilithon, FBOM, and both microbial compartments combined. Comparisons between those two independently measured $\mathrm{NH}_{4}^{+}$uptake rates included data for each of the three defined subreaches (i.e., within reach stations $1-2,2-3$, and 3-4) and for the whole-reach level $(n=4)$. Scaling up calculations was done using both average and median values of habitat-specific $\mathrm{NH}_{4}^{+}$uptake rates in epilithon and $\mathrm{FBOM}$, which were then weighted by the measured riffle and pool area within each sub-reach and whole-reach. Further details are provided in Fig. 5. All statistical tests were done using R 3.0.0 (R Development Core Team 2013).

\section{RESULTS}

\section{Whole-reach $\mathrm{NH}_{4}^{+}$uptake rates}

Values of $\mathrm{NH}_{4}^{+}-S_{\mathrm{w}}$ were relatively short and similar in the two reaches averaging $58 \mathrm{~m}$, while $\mathrm{NH}_{4}^{+} V_{\mathrm{f}}$ and total $\mathrm{NH}_{4}^{+}-U$ were slightly higher at the $\mathrm{OR}$ than at the $\mathrm{SR}$ (Table 1). Total regeneration of $\mathrm{N}$ assimilated by stream biotic compartments was larger at the SR than at OR (Table 1). Assimilatory $\mathrm{NH}_{4}^{+}$uptake calculated from the sum of compartment-specific $\mathrm{NH}_{4}^{+}$uptake rates accounted for $24 \%$ and $9 \%$ of the total $\mathrm{NH}_{4}^{+}$uptake at the OR and $\mathrm{SR}$, respectively (Table 1). Nitrification rates were around two orders of magnitude lower than assimilatory $\mathrm{NH}_{4}^{+}$ uptake in each study reach (i.e., $\sim 0.4 \mathrm{mg} \mathrm{N} \cdot \mathrm{m}^{-2} \cdot \mathrm{d}^{-1}$ ),
TABLE 1. Summary of total and assimilatory $\mathrm{NH}_{4}^{+}$uptake rates in each study reach.

\begin{tabular}{lll}
\hline \hline Parameter & Open & Shaded \\
\hline Total uptake & & \\
$\mathrm{NH}_{4}^{+}-S_{\mathrm{w}}(\mathrm{m})$ & $55.73 \pm 5.4$ & $60.44 \pm 2.6$ \\
$\mathrm{NH}_{4}^{+} V_{\mathrm{f}}(\mathrm{m} / \mathrm{min})$ & $3.40 \times 10^{-3}$ & $2.15 \times 10^{-3}$ \\
$\mathrm{NH}_{4}^{+}-U\left(\mathrm{mg} \mathrm{N} \cdot \mathrm{m}^{-2} \cdot \mathrm{d}^{-1}\right)$ & 73.38 & 57.03 \\
$\quad$ Total $\mathrm{N}$ regeneration $\left(\mathrm{d}^{-1}\right)$ & 0.16 & 0.52 \\
Assimilatory uptake & & \\
$\mathrm{NH}_{4}^{+} S_{\mathrm{w}}(\mathrm{m})$ & 233.95 & 667.20 \\
$\mathrm{NH}_{4}^{+}-V_{\mathrm{f}}(\mathrm{m} / \mathrm{min})$ & $8.04 \times 10^{-4}$ & $1.95 \times 10^{-4}$ \\
$\mathrm{NH}_{4}^{+}-U\left(\mathrm{mg} \cdot \mathrm{N} \cdot \mathrm{m}^{-2} \cdot \mathrm{d}^{-1}\right)$ & 17.37 & 5.18 \\
${\mathrm{Percentage} \mathrm{of} \mathrm{total} \mathrm{NH}_{4}^{+}}_{\quad \text { uptake }}^{23.6 \%}$ & $9.1 \%$ \\
\hline
\end{tabular}

Notes: Parameters of total $\mathrm{NH}_{4}^{+}$uptake (mean $\pm \mathrm{SE}$ for $S_{\mathrm{w}}$ ) were calculated from the decay in tracer ${ }^{15} \mathrm{~N}_{-} \mathrm{NH}_{4}^{+}$flux along the reach, while parameters for assimilatory $\mathrm{NH}_{4}^{+}$uptake were calculated by scaling up the sum of compartment-specific $\mathrm{NH}_{4}^{+}$ uptake rates at whole-reach scale for each measured compartment. Total regeneration is estimated from the tracer ${ }^{15} \mathrm{~N}-\mathrm{NH}_{4}^{+}$ flux in the water column after $14 \mathrm{~h}$ of the end of the addition.

indicating that assimilatory $\mathrm{NH}_{4}^{+}$uptake accounted for the largest proportion of $\mathrm{NH}_{4}^{+} U$ estimated from ${ }^{15} \mathrm{~N}$ decay in the water columns. Both assimilatory $\mathrm{NH}_{4}^{+}-V_{\mathrm{f}}$ and $\mathrm{NH}_{4}^{+}-U$ were much higher at the OR (Table 1), where the number of different benthic compartments contributing to assimilatory $\mathrm{NH}_{4}^{+}$uptake was greater than at the SR.

\section{Contribution of benthic compartments to whole-reach $\mathrm{NH}_{4}^{+}$uptake}

Stream $\mathrm{N}$ biomass was dominated by FBOM even though it only covered $\sim 25 \%$ of the stream bed at each study reach (Table 2). Epilithon was the second benthic compartment contributing the most to stream $\mathrm{N}$ biomass, regardless of the study reach (Table 2). Together epilithon and FBOM allocated the vast majority of stream $\mathrm{N}$ biomass, while other autotrophic compartments such as filamentous algae and bryophytes had also an important contribution to stream $\mathrm{N}$ biomass, especially at the $\mathrm{OR}$ (Table 2).

Microbial $\mathrm{NH}_{4}^{+}$uptake (i.e., sum of epilithon and FBOM) had a high and similar contribution to wholereach $\mathrm{NH}_{4}^{+}$uptake at the two reaches $(57 \%$ at the OR, $60 \%$ at the SR). The sum of compartment-specific $\mathrm{NH}_{4}^{+}$ uptake rates at the OR was strongly dominated by FBOM, while in the SR, epilithon was the compartment with the highest contribution at reach scale (Table 2). In fact, $\mathrm{NH}_{4}^{+}$uptake rates of each benthic compartment were similar among the two reaches, except for FBOM which showed much lower rates at the SR (Table 2). Nitrogen turnover rates of epilithon were one order of magnitude faster than those of FBOM at both study reaches (Table 2). Low turnover rates of FBOM combined with its large contribution to assimilatory $\mathrm{NH}_{4}^{+}$uptake at the OR (Table 2) are in agreement with the lower whole-reach $\mathrm{N}$ regeneration observed at the OR (Table 1). 
TABLE 2. Reach-weighted $\mathrm{N}$ standing stocks, compartment-specific $\mathrm{NH}_{4}^{+}$uptake, and turnover rates for the different benthic compartments at each study reach.

\begin{tabular}{|c|c|c|c|c|c|c|}
\hline \multirow[b]{2}{*}{ Compartment } & \multicolumn{2}{|c|}{$\mathrm{N}$ standing stock $\left(\mathrm{mg} \mathrm{N} / \mathrm{m}^{2}\right)$} & \multicolumn{2}{|c|}{$\mathrm{NH}_{4}^{+}$uptake rate $\left(\mathrm{mg} \mathrm{N} \cdot \mathrm{m}^{-2} \cdot \mathrm{d}^{-1}\right)$} & \multicolumn{2}{|c|}{$\mathrm{N}$ turnover $\left(\mathrm{d}^{-1}\right)$} \\
\hline & Open & Shaded & Open & Shaded & Open & Shaded \\
\hline Epilithon & 16.09 & 32.84 & $2.80(0.23)$ & $2.23(0.10)$ & $1.24(0.11)$ & $0.37(0.16)$ \\
\hline FBOM & 164.63 & 45.89 & $7.23(0.81)$ & $0.94(0.11)$ & $0.26(0.09)$ & $0.03(0.06)$ \\
\hline \multicolumn{7}{|l|}{ Filamentous algae } \\
\hline Cladophora sp. & 10.68 & & $5.13(0.35)$ & & $0.44(0.33)$ & \\
\hline Lemanea sp. & 4.30 & 12.56 & $0.72(0.10)$ & $0.58(0.08)$ & $0.44(0.33)$ & $0.49(0.11)$ \\
\hline Oedogonium sp. & 0.91 & 5.16 & $0.22(0.01)$ & $0.67(0.10)$ & $0.18(0.15)$ & $0.15(0.26)$ \\
\hline Bryophytes & 12.06 & 8.89 & $1.12(0.13)$ & $0.68(0.11)$ & $0.09(0.20)$ & $0.04(0.04)$ \\
\hline Macrophytes & 5.49 & & $0.13(0.01)$ & & $0.47(0.91)$ & \\
\hline CBOM & 4.37 & 8.14 & $0.02(0.00)$ & $0.12(0.05)$ & $0.15(0.21)$ & $0.45(0.51)$ \\
\hline
\end{tabular}

Notes: Data of $\mathrm{NH}_{4}^{+}$uptake rates correspond to mean values (SEM in parentheses) calculated from measures at each reach station $(n=9-10)$. Data of turnover rates correspond to the slope of the regression (SEM in parentheses) between $\delta^{15} \mathrm{~N}$ values from postaddition samples collected at reach stations $1-3$ ( $n=3$ over time). FBOM, fine benthic organic matter.

The total ${ }^{15} \mathrm{~N}$ tracer stored by benthic compartments at the end of the addition accounted for $26 \%$ and $8 \%$ of added ${ }^{15} \mathrm{~N}$ at the OR and SR, respectively. Total mass of added ${ }^{15} \mathrm{~N}$ which was recovered at the end of the experiment (i.e., biological storage and export) was $\sim 40$ at the OR and $\sim 20 \%$ at the SR. Relatively low ${ }^{15} \mathrm{~N}$ mass recovery might be related to a dominance of downwelling points measured along each study reach (data not shown). About $60 \%$ of total ${ }^{15} \mathrm{~N}$ storage in each study reach was dominated by microbial compartments (Appendix S2). However, microbial $\mathrm{N}$ storage was dominated by FBOM at the OR and by epilithon at the SR (Appendix S2).

\section{Spatial heterogeneity in hydraulics and structure of microbial compartments}

Water depth and velocity were on average similar among the two reaches and microbial compartments (Table 3) and showed most of their spatial variation located at the microhabitat and habitat scales (Table 4). In terms of microbial structure, epilithon was the compartment showing more significant differences between the two study reaches (Table 3 ). Specifically, N content, chl $a$, and cyanobacteria and diatoms abundance in epilithon were higher at the SR compared to the OR (Table 3). Only $\delta^{15} \mathrm{~N}$ natural abundances showed significant differences between the two reaches for both microbial compartments with higher $\delta^{15} \mathrm{~N}$ signatures at the OR for epilithon and at the SR in the case of FBOM (Table 3). Overall, spatial variation in the structure of microbial communities was primarily associated with microhabitat heterogeneity (Table 4). However, for each structural parameter considered, epilithon showed greater variation at the habitat and reach scale compared to FBOM compartment (Table 4). Variation in extracellular enzymatic activities was mainly associated with variation at the habitat and microhabitat scales, regardless of the compartment considered (Table 4).

\section{Spatial heterogeneity in $N$ cycling rates of microbial compartments}

Differences in both patch-specific $\mathrm{NH}_{4}^{+}$uptake rates and $\mathrm{N}$ turnover rates between the two reaches were much larger for FBOM than for epilithon, with three times higher FBOM uptake and turnover rates at the OR than at the SR (Table 3). Spatial variation in epilithon $\mathrm{NH}_{4}^{+}$ uptake and turnover rates was principally observed at the habitat scale, followed by microhabitat variation and by almost no variation between the two study reaches (Table 4). On the contrary, spatial variation in $\mathrm{NH}_{4}^{+}$ uptake rates of FBOM was principally located at the reach scale, while variation in FBOM turnover rates showed a similar pattern to that observed for epilithon (Table 4). Overall, spatial variance in microbial $\mathrm{N}$ uptake decreased as the grain of the scale considered increased (Appendix S3). Probability distributions of microbial N processing rates were right-skewed and therefore dominated by low values of $\mathrm{N}$ uptake rates, regardless of the compartment and reach considered (Fig. 2). Significant differences in the probability distribution of $\mathrm{N}$ uptake and turnover rates between the two reaches were only observed for FBOM (Fig. 2). Specifically, $\mathrm{NH}_{4}^{+}$uptake rates of $\mathrm{FBOM}$ at the $\mathrm{OR}$ showed a more normal distribution compared to those at the SR (Fig. 2).

Nonlinear distributions of $\mathrm{NH}_{4}^{+}$uptake rates in epilithon and FBOM resulted in unequal distribution of $\mathrm{NH}_{4}^{+}$uptake along the study reaches, especially for epilithon. Reach-specific regressions providing the best fit (i.e., highest $r^{2}$ ) between water depth and $\mathrm{NH}_{4}^{+}$uptake rates of epilithon $\left(\mathrm{OR}\right.$, uptake $=18.6 \times \mathrm{depth}^{-0.87}$, $r^{2}=0.66 ; \mathrm{SR}$, uptake $=12.6 \times$ depth $\left.^{-0.96}, r^{2}=0.53\right)$ were used to map epilithon $\mathrm{NH}_{4}^{+}$uptake within each study reach (Fig. 3). Results showed large heterogeneity in epilithon $\mathrm{NH}_{4}^{+}$uptake rates at the microhabitat scale with hot spots of $\mathrm{NH}_{4}^{+}$uptake rates (i.e., red zones) occupying a small percentage of the total reach area and being 
TABLE 3. Spatial variation in epilithon and FBOM structure and function within and among the two study reaches.

\begin{tabular}{|c|c|c|c|c|c|c|}
\hline \multirow[b]{2}{*}{ Parameter } & \multicolumn{3}{|c|}{ Eplitihon } & \multicolumn{3}{|c|}{ Fine benthic organic matter } \\
\hline & Open & Shaded & $P$ & Open & Shaded & $P$ \\
\hline Water depth $(\mathrm{cm})$ & $10.1(1.2)$ & $11.2(1.3)$ & 0.939 & $13.9(1.2)$ & $11.9(1)$ & 0.918 \\
\hline Water velocity $(\mathrm{m} / \mathrm{s})$ & $0.2(0.0)$ & $0.06(0.0)$ & 0.190 & $0.04(0.0)$ & $0.05(0.0)$ & 0.563 \\
\hline Nitrogent content $(\%)$ & $0.4(0.0)$ & $0.5(0.0)$ & $<0.05$ & $0.3(0.0)$ & $0.3(0.0)$ & 0.361 \\
\hline Nitrogen biomass ( $\left.\mu \mathrm{g} \mathrm{N} / \mathrm{cm}^{2}\right)$ & $3.4(0.2)$ & $5.4(0.7)$ & 0.317 & $63.3(6.9)$ & $25.4(1.4)$ & 0.086 \\
\hline Molar C:N & $11.7(0.3)$ & $9.86(0.2)$ & $<0.05$ & $12.6(0.2)$ & $13.2(0.2)$ & 0.294 \\
\hline Green algae abundance $\left(\mu \mathrm{g} / \mathrm{cm}^{2}\right)$ & $0.5(0.1)$ & $0.3(0.1)$ & 0.264 & $0.001(0.0)$ & $0.01(0.0)$ & 0.609 \\
\hline Cyanobacteria abundance $\left(\mu \mathrm{g} / \mathrm{cm}^{2}\right)$ & $0.3(0.0)$ & $0.7(0.1)$ & $<0.01$ & $0.3(0.0)$ & $0.2(0.1)$ & 0.059 \\
\hline Diatoms abundance $\left(\mu \mathrm{g} / \mathrm{cm}^{2}\right)$ & $1.1(0.1)$ & $2.6(0.3)$ & $<0.001$ & $1.3(0.1)$ & $1.1(0.1)$ & 0.367 \\
\hline Total chl $a\left(\mu \mathrm{g} / \mathrm{cm}^{2}\right)$ & $1.8(0.1)$ & $3.6(0.3)$ & $<0.01$ & $1.6(0.2)$ & $1.3(0.2)$ & 0.252 \\
\hline Chl $a$ : AFDM & $0.6(0.1)$ & $1.1(0.1)$ & 0.187 & $0.06(0.0)$ & $0.09(0.0)$ & 0.167 \\
\hline$\delta^{13} \mathrm{C}$ signature (\%o) & $-27.6(0.6)$ & $-26.5(0.4)$ & 0.355 & $-28.2(0.1)$ & $-28.5(0.1)$ & 0.406 \\
\hline$\delta^{15} \mathrm{~N}$ signature $(\% 0)$ & $2.7(0.1)$ & $1.9(0.1)$ & $<0.01$ & $2.3(0.3)$ & $3.2(0.2)$ & $<0.05$ \\
\hline $\begin{array}{l}\text { Aminopeptidase activity }(\mu \mathrm{mol} \\
\left.\text { AMC }^{\prime} \mathrm{g} \mathrm{AFDM}^{-1} \cdot \mathrm{h}^{-1}\right)\end{array}$ & $76.9(6.1)$ & $29.1(1.8)$ & 0.115 & $6.9(0.3)$ & $9.6(0.9)$ & 0.446 \\
\hline $\begin{array}{l}\beta \text {-glucosidase activity }(\mu \mathrm{mol} \text { MUF·g } \\
\left.\text { AFDM }^{-1} \cdot h^{-1}\right)\end{array}$ & $3.4(0.3)$ & $1.6(0.3)$ & 0.321 & $1.1(0.1)$ & $2.5(0.1)$ & 0.709 \\
\hline $\begin{array}{l}\text { Extracellular polymeric substances } \\
\quad\left(\mu \mathrm{g} \text { glucose-eq } / \mathrm{cm}^{2}\right)\end{array}$ & $18.3(1.3)$ & $21.3(1.1)$ & 0.154 & & & \\
\hline $\mathrm{N}-\mathrm{NH}_{4}^{+}$uptake rate $\left(\mathrm{mg} \mathrm{N} \cdot \mathrm{m}^{-2} \cdot \mathrm{d}^{-1}\right)$ & $3.93(0.7)$ & $2.77(0.4)$ & 0.489 & $17.77(2)$ & $3.23(0.4)$ & $<0.01$ \\
\hline $\mathrm{N}$ turnover rate $\left(\mathrm{d}^{-1}\right)$ & $0.11(0.01)$ & $0.08(0.001)$ & 0.308 & $0.04(0.001)$ & $0.01(0.001)$ & 0.340 \\
\hline
\end{tabular}

Notes: Data ( $n=30$ for each compartment and reach) correspond to mean values (SEM in parentheses) and $P$ values represent results from mixed-model nested ANOVA with reach as the fixed main factor and habitat as a random nested factor. $\mathrm{P}$ values $<0.05$ in bold type indicate significant differences between the study reaches.

TABLE 4. Results of the variance component model with reach and habitat (nested within reach) as random factors.

\begin{tabular}{|c|c|c|c|c|c|c|}
\hline \multirow[b]{2}{*}{ Parameter } & \multicolumn{3}{|c|}{ Eplitihon } & \multicolumn{3}{|c|}{ Fine benthic organic matter } \\
\hline & Reach & Habitat & Microhabitat & Reach & Habitat & Microhabitat \\
\hline Water depth & $<0.01$ & 28.9 & 71.1 & $<0.01$ & 26.8 & 73.2 \\
\hline Water velocity & 7.2 & 31.8 & 61 & $<0.01$ & 7.9 & 92.1 \\
\hline Nitrogen content & 30.8 & 27.9 & 41.3 & $<0.01$ & 24.2 & 75.8 \\
\hline Nitrogen biomass & 1.5 & 81 & 17.5 & 30 & 56.3 & 13.7 \\
\hline Molar C:N & 43.5 & 22.4 & 34.1 & 0.7 & 14.6 & 84.7 \\
\hline Green algae abundance & 2.7 & 27 & 70.3 & 4 & $<0.01$ & 96 \\
\hline Cyanobacteria abundance & 31 & 4.1 & 64.9 & 7.9 & 0.6 & 91.5 \\
\hline Diatoms abundance & 49.2 & 1.1 & 49.7 & $<0.01$ & 7.7 & 92.3 \\
\hline Total chl $a$ & 40.3 & 12.2 & 47.5 & 1.9 & 5.9 & 92.2 \\
\hline Chl $a$ :AFDM & 10.1 & 52.8 & 37.1 & 6.7 & 18.3 & 75 \\
\hline$\delta^{13} \mathrm{C}$ signature & $<0.01$ & 46.6 & 53.4 & $<0.01$ & 21.3 & 78.7 \\
\hline$\delta^{15} \mathrm{~N}$ signature & 35.9 & 9 & 55.1 & 24.5 & 7.2 & 68.3 \\
\hline Aminopeptidase activity & 21.4 & 64.6 & 14 & $<0.01$ & 57.2 & 42.8 \\
\hline$\beta$-glucosidase activity & 0.2 & 48 & 51.8 & $<0.01$ & 38 & 62 \\
\hline EPS & 9.6 & $<0.01$ & 90.4 & & & \\
\hline $\mathrm{N}-\mathrm{NH}_{4}^{+}$uptake rate & $<0.01$ & 68.8 & 31.2 & 60.8 & 20.6 & 18.6 \\
\hline $\mathrm{N}$ turnover rate & 1.3 & 62.8 & 35.9 & $<0.01$ & 25.6 & 74.4 \\
\hline
\end{tabular}

Notes: Data correspond to percent variation in biotic, physical, and chemical parameters measured in our study associated with each particular scale: reach, habitat, and microhabitat (as the residual variation of the model). EPS, Extracellular Polymeric Substances.

generally located within riffle habitats of any of the two reaches (Fig. 3). In the case of $\mathrm{NH}_{4}^{+}$uptake rates of FBOM, we only found a significant but positive regression with depth at the OR (uptake $=3.4 \exp ^{0.09 * \text { depth }}, r^{2}=0.53$;
Fig. 3), where zones of high $\mathrm{NH}_{4}^{+}$uptake by FBOM represented a large percentage of the total streambed in contrast with the spatial distribution observed for $\mathrm{NH}_{4}^{+}$ uptake by epilithon (Fig. 3). 
A
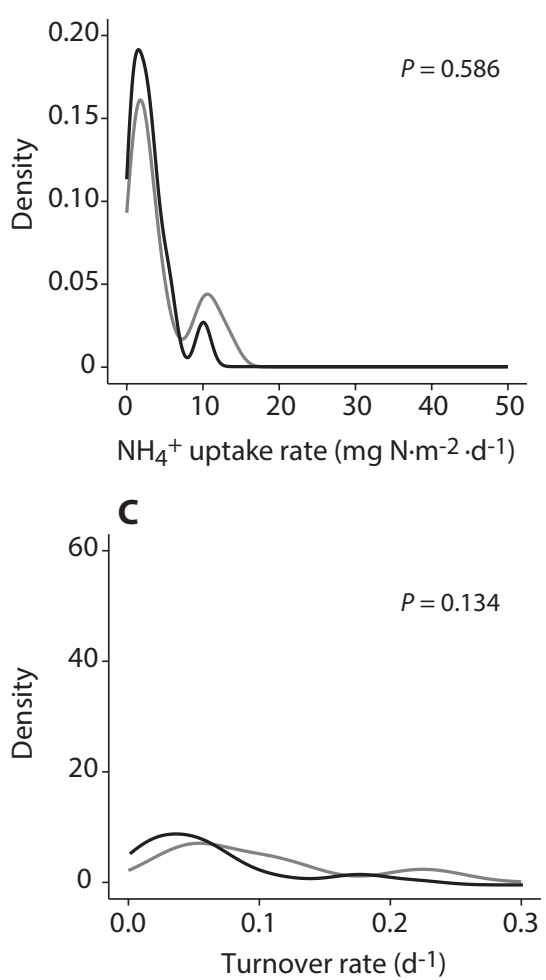

B

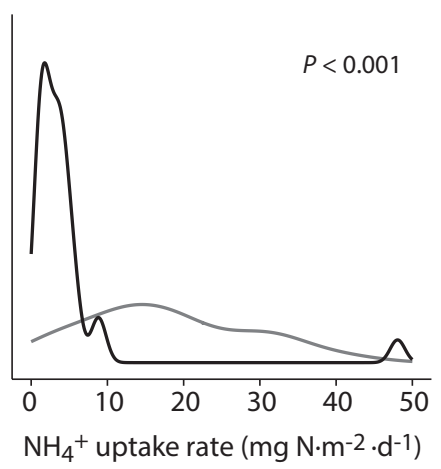

D

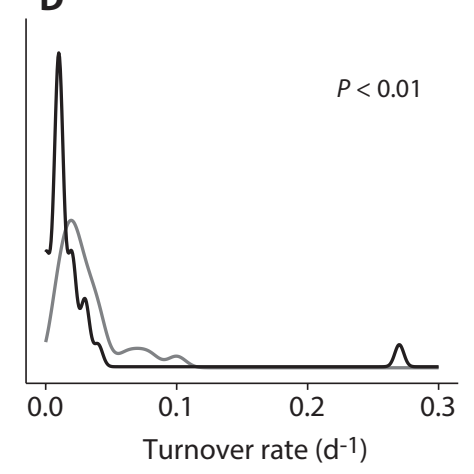

FIG. 2. Kernel density estimations (KDE) for patch-specific $\mathrm{NH}_{4}^{+}$uptake and $\mathrm{N}$ turnover rates of (A, C) epilithon and (B, D) fine benthic organic matter (FBOM) at the open (gray lines) and shaded (black lines) reaches. The bandwidth was adjusted to 0.1 , $n=30$ replicates for each compartment and reach.

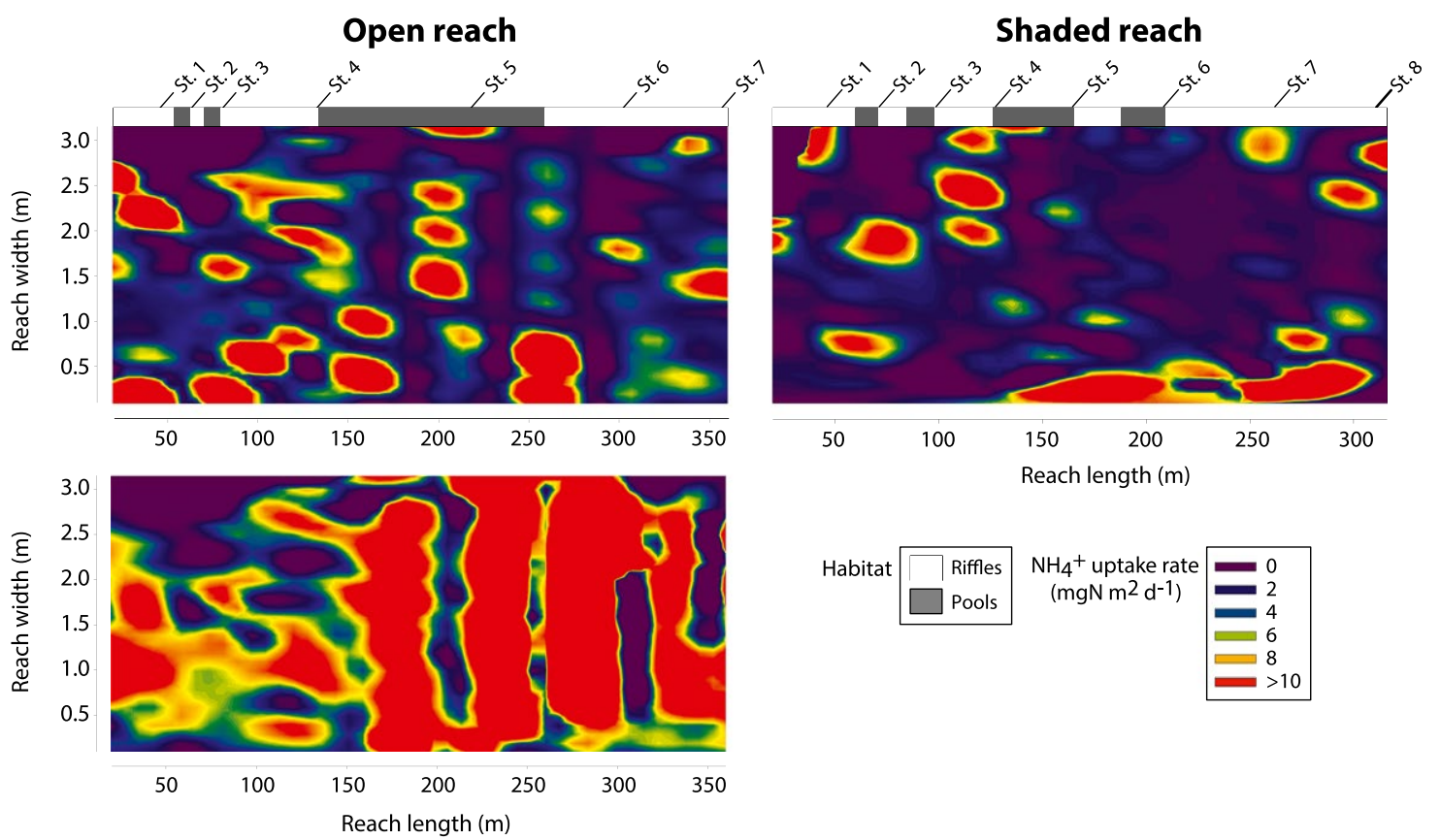

FIG. 3. Spatial variability of patch-specific $\mathrm{NH}_{4}^{+}$uptake rates for epilithic (upper panels) and FBOM (bottom panel) microbial compartments in the open and shaded reaches. Data is derived from the hydromorphological configuration of each stream reach and the significant relationship between $\mathrm{NH}_{4}^{+}$uptake rates of epilithon and $\mathrm{FBOM}$ and water depth. Bands at the top of each panel indicate the location of reach stations and the distribution and longitudinal extend of riffle and pool habitats in each reach. Reach stations for each study reach are indicated as St. 1-8. 


\section{Local drivers of small-scale heterogeneity in microbial $N$ cycling}

Results of LME models showed that spatial variation of epilithon $\mathrm{NH}_{4}^{+}$uptake was principally explained by water velocity, with more than $80 \%$ of the total variance of the random effects attributed to the nested habitat effect and almost no variation associated with the reach effect (Table 5). Since all variables used in LME models were log-transformed, these results indicate a strong nonlinear correlation between water velocity and epilithon $\mathrm{NH}_{4}^{+}$uptake rates with no stream reach effect on the slope of the relationship (Fig. 4). Similarly, spatial variation of $\mathrm{NH}_{4}^{+}$uptake rates in $\mathrm{FBOM}$ was also significantly explained by water velocity in addition with the abundance of diatoms in each microhabitat patch (Table 5). However, variation explained by random effects was mostly attributed to the reach effect (Table 5), which is illustrated by reach-specific slopes observed for the relationship between water velocity and FBOM uptake rates and by greater uptake rates in the OR compared to the SR for the same range of water velocities (Fig. 4). Reachspecific slopes were also observed for the relationship between diatoms abundance and $\mathrm{FBOM} \mathrm{NH}_{4}^{+}$uptake (OR 0.23, SR -0.12). LME models for microbial $\mathrm{N}$ turnover showed similar results of fixed effects for both epilithon and FBOM with $\mathrm{N}$ content (negatively related) and water velocity (positively related) as the main drivers of their $\mathrm{N}$ turnover rates (Table 5). However, as observed for uptake LME models, most of the variance of the random effects in epilithon was attributed to the nested habitat effect and to reach and habitat effects in the case of FBOM (Table 5).

\section{Comparisons between reach-scale $\mathrm{NH}_{4}^{+}$uptake and scaled up microbial $\mathrm{NH}_{4}^{+}$uptake}

Scaling up observed variation in habitat-specific $\mathrm{NH}_{4}^{+}$ uptake rates of epilithon and FBOM at sub-reach and whole-reach scale had different effects depending on the study reach and the microbial compartment considered. Overall, the use of habitat mean values for $\mathrm{NH}_{4}^{+}$uptake resulted in no significant correlations between independently measured reach-scale $\mathrm{NH}_{4}^{+}$uptake rates from the water column and scaled up microbial $\mathrm{NH}_{4}^{+}$uptake (data not shown). Contrastingly, median habitat values for $\mathrm{NH}_{4}^{+}$uptake of $\mathrm{FBOM}$ showed a significant and positive correlation with reach-scale $\mathrm{NH}_{4}^{+}$uptake at the $\mathrm{OR}$ (Fig. 5). A significant correlation was also observed at the OR when comparing measured reach-scale $\mathrm{NH}_{4}^{+}$

TABLE 5. Spatial relationships between structural (biological and physical characteristics of microhabitat patches) and functional $\left(\mathrm{N}-\mathrm{NH}_{4}^{+}\right.$uptake and turnover rates) features of epilithon and FBOM predicted by linear mixed-effects models accounting for the random effects of the hierarchical design employed.

\begin{tabular}{|c|c|c|c|c|c|c|c|c|}
\hline \multirow[b]{2}{*}{ Effects } & \multicolumn{5}{|c|}{ Fixed effects } & \multicolumn{3}{|c|}{ Random effects } \\
\hline & Estimate & SEM & $\mathrm{df}$ & $t$ & $\bar{P}$ & Reach & Habitat & Microhabitat \\
\hline \multicolumn{9}{|l|}{$\mathrm{N}-\mathrm{NH}_{4}^{+}$uptake rate } \\
\hline \multicolumn{9}{|l|}{ Epilithon } \\
\hline Intercept & 0.695 & 0.096 & 47 & 7.205 & $<0.001$ & & & \\
\hline Water velocity & 0.222 & 0.039 & 47 & 5.564 & $<0.001$ & & & \\
\hline Variation explained $(\%)$ & & & & & & $<0.01$ & 87 & 13 \\
\hline \multicolumn{9}{|l|}{ FBOM } \\
\hline Intercept & 0.205 & 0.311 & 43 & 0.659 & 0.513 & & & \\
\hline Water velocity & 0.237 & 0.07 & 43 & 3.387 & $<0.01$ & & & \\
\hline Diatoms abundance & 0.804 & 0.167 & 43 & 4.806 & $<0.001$ & & & \\
\hline Variation explained $(\%)$ & & & & & & 65.9 & 30.5 & 3.6 \\
\hline \multicolumn{9}{|l|}{$\mathrm{N}$ turnover rate } \\
\hline \multicolumn{9}{|l|}{ Epilithon } \\
\hline Intercept & -1.421 & 0.115 & 45 & -12.291 & $<0.001$ & & & \\
\hline Water velocity & 0.160 & 0.028 & 45 & 5.689 & $<0.001$ & & & \\
\hline $\mathrm{N}$ content & -1.171 & 0.071 & 45 & -16.664 & $<0.001$ & & & \\
\hline Green algae abundance & 0.053 & 0.014 & 45 & -3.692 & $<0.001$ & & & \\
\hline Variation explained (\%) & & & & & & $<0.01$ & 83.2 & 16.8 \\
\hline \multicolumn{9}{|l|}{ FBOM } \\
\hline Intercept & -0.792 & 0.233 & 44 & -3.392 & $<0.01$ & & & \\
\hline $\mathrm{N}$ content & -1.532 & 0.316 & 44 & -4.849 & $<0.01$ & & & \\
\hline Water velocity & 0.299 & 0.086 & 44 & 3.472 & $<0.01$ & & & \\
\hline Variation explained $(\%)$ & & & & & & 35.2 & 40.6 & 24.2 \\
\hline
\end{tabular}

Notes: The percentage of variance explained by each random effect (habitat nested in reach; and microhabitat as the residual variation of the model) is reported. All explanatory and response variables were log-transformed. Best model selection was based on minimum Akaike information criterion (AIC) after following an all subsets routine. 

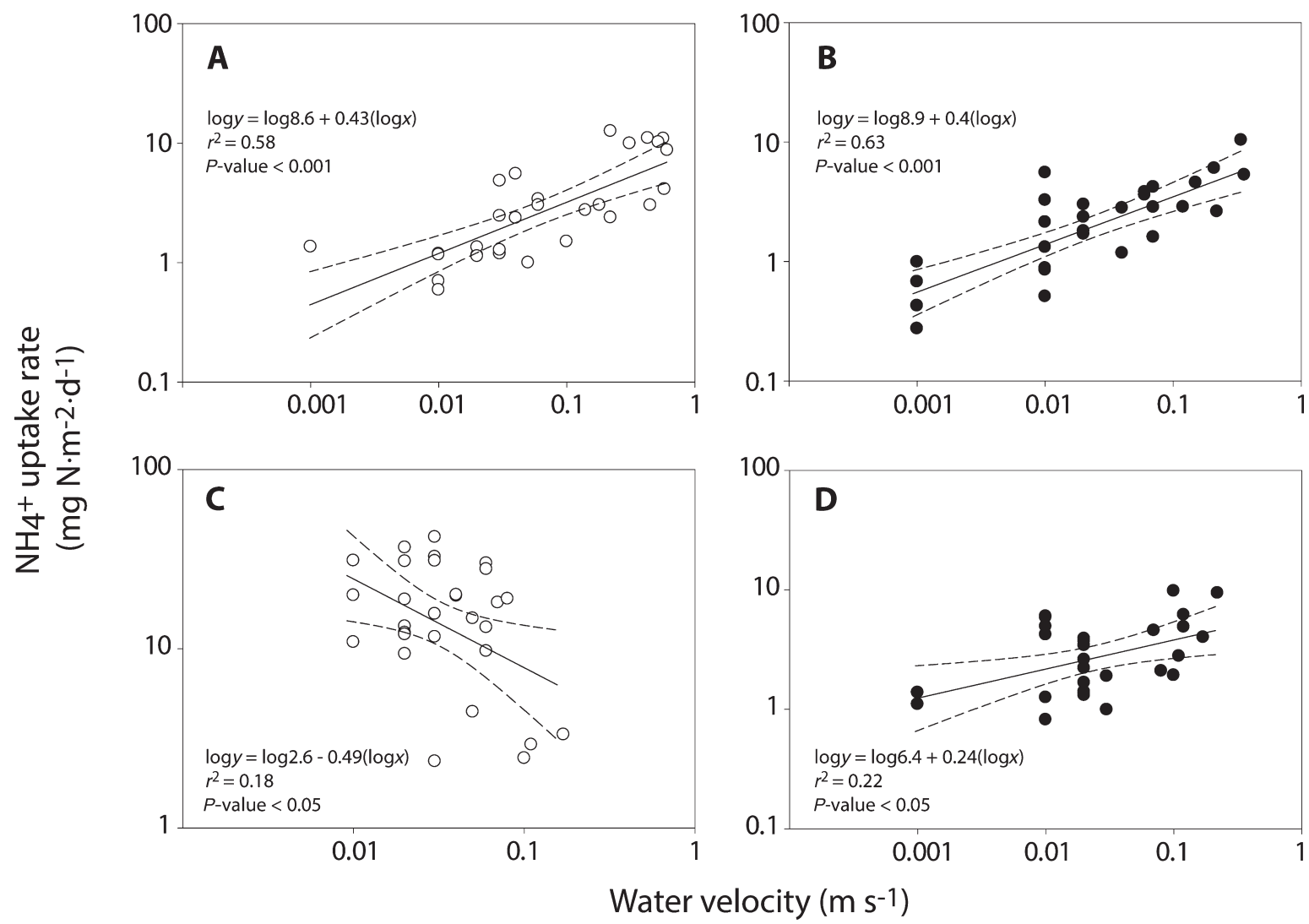

FIG. 4. Linear regressions between water velocity and $\mathrm{NH}_{4}^{+}$uptake rates of (A, B) epilithon and (C, D) FBOM. Note that both axes are expressed in a logarithmic scale. Dashed bands represent $95 \%$ confidence regions. Open and solid dots represent data from open and shaded reach, respectively.

uptake rates and scaled up $\mathrm{NH}_{4}^{+}$uptake from both microbial compartments combined (Fig. 5), which is likely related to the important contribution of FBOM to $\mathrm{NH}_{4}^{+}$assimilatory uptake at the OR (Table 2). Overall, better results were obtained using median than mean microbial $\mathrm{NH}_{4}^{+}$uptake which is concordant with the right-skewed distribution observed for microbial $\mathrm{NH}_{4}^{+}$ uptake rates at both study reaches (Fig. 2).

\section{Discussion}

At the reach scale, environmental constraints and emergent properties from small spatial scales can be conceptualized as exogenous and endogenous sources of variability in patterns of microbial $\mathrm{N}$ uptake, respectively. Understanding how the relative importance of these two sources of variability changes across space and over time in stream ecosystems will increase our capacity to predict streams responses to a changing environment. Results from this study provide a good characterization of the small-scale heterogeneity in microbial $\mathrm{N}$ uptake rates, which constitute an essential step to determine how pattern-process relationships of stream $\mathrm{N}$ cycling interact from small to large scales (Peters et al. 2007, Turner and Chapin 2005). Small-scale heterogeneity in microbial N uptake ranged by three orders of magnitude regardless of the study reach, which is comparable to the range observed at the ecosystem level for 12 headwater streams across different biomes (Peterson et al. 2001). Spatial heterogeneity in nitrification (Kemp and Dodds 2001) and denitrification processes (Knapp et al. 2009) measured at similar scales showed similar ranges of spatial variation compared to microbial $\mathrm{N}$ uptake. However, besides the range of absolute rates, it is the patch distribution in $\mathrm{N}$ processing rates what has the most significant implications when aggregating local processes at larger scales. In this regard, heterogeneity in microbial $\mathrm{N}$ uptake rates at small scales was characterized by the presence of hot spots of $\mathrm{N}$ uptake, which are defined as isolated patches of enhanced biogeochemical activity (McClain et al. 2003, Harms and Grimm 2008). Hot spots, by definition, occupied a small fraction of the total space and their presence led to a heterogeneous distribution of $\mathrm{N}$ uptake rates within the stream channel.

Reach-scale $\mathrm{NH}_{4}^{+}$uptake rates measured in this study were similar to previous values for open (Dodds et al. 2000, Simon et al. 2007) and shaded (Mulholland et al. 2000, Tank et al. 2000, Merriam et al. 2002) streams. In contrast, the low nitrification rates measured in our study 


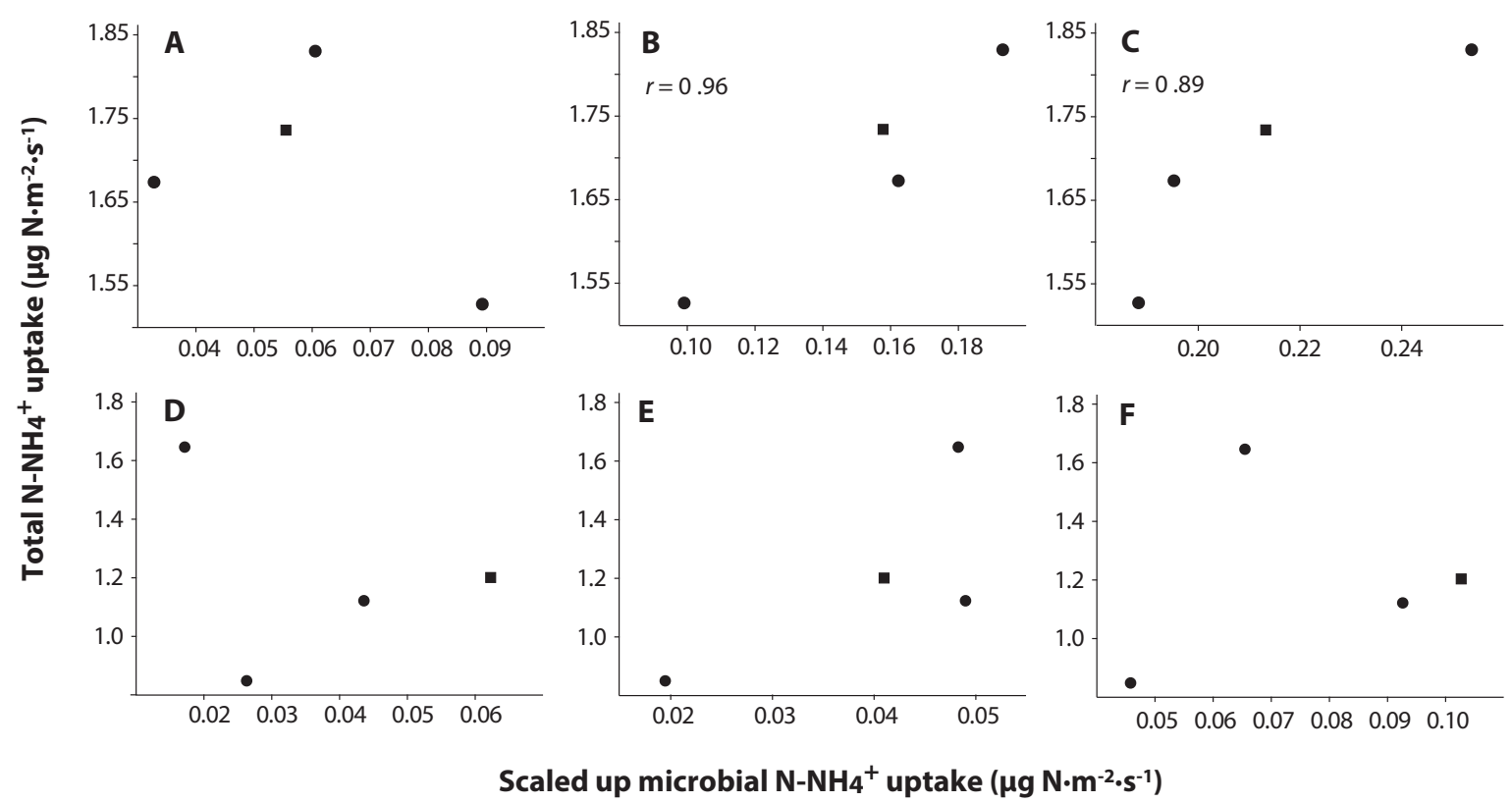

FIG. 5. Reach-specific correlations between total $\mathrm{NH}_{4}^{+}$uptake measured from the ${ }^{15} \mathrm{~N}-\mathrm{NH}_{4}^{+}$decay in the water column and scaled up $\mathrm{NH}_{4}^{+}$uptake rates of (A, D) epilithon, (B, E) FBOM, and (C, F) both microbial compartments combined. Circles represent $\mathrm{NH}_{4}^{+}$uptake rates at the sub-reach scale (i.e., between reach station 1-2, 2-3, and 3-4) and square symbols represent $\mathrm{NH}_{4}^{+}$uptake rates at the whole-reach scale. Scaled-up values at the sub-reach and whole-reach scale were calculated using habitat-specific median $\mathrm{NH}_{4}^{+}$uptake rates and the percent cover of each habitat within each sub-reach and whole reach, respectively. Correlation coefficients are only shown for significant correlations $(P<0.05)$.

contrasted with previous data (Mulholland et al. 2000, Merriam et al. 2002) indicating that total $\mathrm{NH}_{4}^{+}$uptake in our reaches was dominated by assimilatory $\mathrm{NH}_{4}^{+}$uptake. In addition, results showed that microbial $\mathrm{N}$ uptake accounted for $>50 \%$ of the assimilatory $\mathrm{NH}_{4}^{+}$uptake in both reaches, evidencing the important role of microbial assemblages as key players in stream $\mathrm{N}$ cycling, and supporting the need to better understand the specific role of environmental constraints and emergent properties on these particular biotic components of streams.

\section{Environmental constraints on microbial $N$ uptake in streams}

The environmental context of each stream ecosystem has a strong influence on the sources of energy and matter to the stream reach, and thus on the relative abundance and composition of microbial compartments at smaller scales (Fig. 1). For instance, patterns in light availability are set at a reach scale but led to a general increase in the abundance of photoautotrophic organisms at the reach and at smaller spatial scales. In particular, structural composition of epilithon showed greater variation within each reach, but also some differences between the two reaches. Algal abundance was significantly lower and heterotrophic activities (i.e., EEA) were higher in epilithon at the OR that at the SR, contrary to the expected enhanced photoautotrophic activity with lower canopy cover. Relatively high EPS values indicated that microbial assemblages in epilithon were mature and thus had a well-developed structure (Romani et al. 2008). Under these conditions, positive feedbacks between algae and heterotrophic bacteria within epilithon has been previously described (Romani and Sabater 1999, Rier and Stevenson 2002, Proia et al. 2012), which may explain the confounding structural response by epilithon to the differences in light availability between the two study reaches. On the other hand, microbial assemblages in FBOM are embedded in a high pool of fine particles mostly from detrital organic matter from autochthonous and allocthonous origin (Bonin et al. 2000, Findlay et al. 2002, Sakamaki and Richardson 2013). Riparian canopy cover is therefore a critical factor for the composition of FBOM since it is a source of allochthonous organic matter to the stream, and thus ultimately influences the proportion of photoautotrophs and heterotrophs in FBOM (Gessner and Chauvet 1994, Findlay et al. 2002). In our study stream, such environmental influences on FBOM structure have also been related to seasonality with greater algal than bacterial biomass before riparian tree leaf-out in spring (Artigas et al. 2008).

As observed in previous studies, we expected that differences in the environmental constraints associated with each study reach (i.e., variation in light and organic matter inputs) will change patterns of microbial $\mathrm{N}$ uptake at the reach scale by altering the $\mathrm{N}$ demand of microbial compartments. This was indeed the overall 
response of microbial communities showing on average greater $\mathrm{N}$ uptake rates at the $\mathrm{OR}$, a paradigm of how patterns can be directly imposed by larger scale constraints. However, quantification of $\mathrm{N}$ cycling at different scales allowed us to examine how small-scale heterogeneity in $\mathrm{N}$ uptake influenced observed patterns at whole-reach scales for both epilithon and FBOM compartments.

\section{Emergent properties from small-scale heterogeneity in microbial $N$ uptake}

Results from LME models showed that variation in $\mathrm{N}$ uptake of FBOM communities was dominated by differences between the two reaches. Small-scale heterogeneity in $\mathrm{N}$ uptake of FBOM was large in both stream reaches, as well as microhabitat heterogeneity of its principal controlling factors (i.e., water velocity and diatoms abundance). Heterogeneity at small scales in $\mathrm{N}$ uptake by FBOM and its primary drivers was, however, overwhelm by the difference in the environmental constrains of each study reach, which caused large differences in the average $\mathrm{N}$ demand of FBOM communities. This is in agreement with reach-specific slopes in the velocity-uptake and diatoms-uptake relationships observed for FBOM, in which similar values of both water velocity and diatom abundance result in much different $\mathrm{N}$ uptake rates depending on the study reach. Therefore, FBOM responses to changes in environmental constraints observed in our study may indicate the effects of crossscale interactions in which whole-reach patterns in FBOM N uptake are principally overwhelmed by larger scale constraints.

On the other hand, results from LME models showed that variation in epilithon $\mathrm{N}$ uptake was higher at habitat and microhabitat scales with low differences between the two reaches. Small-scale heterogeneity in epilithon $\mathrm{N}$ uptake was significantly explained by heterogeneity in water velocity at microhabitat and habitat scales. The relationship between velocity and $\mathrm{N}$ uptake was similar in the two reaches regardless of differences in the environmental conditions, probably because flow heterogeneity is rather depending on the characteristics of streambed substrata. Although a few significant structural differences in epilithon were observed between the two reaches, the effects of local drivers at smaller scales remain the same and may explain the lack of significant responses of epilithon $\mathrm{N}$ uptake to different streamriparian interactions observed in our study. Therefore, whole-reach patterns in epilithon $\mathrm{N}$ uptake seem to be principally attributed to emerging properties from lower scales.

\section{Flow velocity as a driver of small-scale heterogeneity in microbial $N$ uptake}

Previous work has recognized flow velocity as the "master variable" organizing epilithon composition and succession and suggested that as epilithon matures the effects of water velocity on their structure and composition decreases (Besemer et al. 2007, 2009). Our results, however, suggest that flow velocity exerts an important control on epilithon $\mathrm{N}$ uptake even at late successional stages. This is in agreement with other studies relating flow heterogeneity and epilithon metabolism (Cardinale et al. 2002). The mechanism behind the power function observed in our study between flow velocity and epilithon $\mathrm{N}$ uptake may be explained by an increase of nutrient transfer from the water into the epilithon layers as water velocity increases, which results in increased $\mathrm{N}$ availability and uptake rates. This is in agreement with previous results showing how slow velocities can lead to lower mass transfer into the epilithon matrix due to a higher boundary layer effect (Gantzer et al. 1988, Battin et al. 2003, Singer et al. 2010). This contention is further supported by the negative correlation observed in our study between water velocity and $\delta^{13} \mathrm{C}$ natural abundance of epilithon $(r=0.6, P<0.001)$. Values of $\delta^{13} \mathrm{C}$ in epilithon are known to be higher under low water velocities because of the lower isotopic fractionating caused by constrains in diffusion rates through the epilithon boundary layer (Finlay et al. 1999, Trudeau and Rasmussen 2003).

The nonlinear relationship between water velocity and epilithon $\mathrm{N}$ uptake at the microhabitat level showed a similar slope than that observed from results at the whole-reach scale from 30 different headwater streams (Fig. 6). At the reach scale, however, streams with higher water velocities show lower $\mathrm{N}$ uptake relative to the $\mathrm{N}$ flux, i.e., longer uptake lengths (Valett et al. 1996, Butturini and Sabater 1998, Peterson et al. 2001). This is explained on the basis that increased water velocities, and associated increases in depth, lead to a lower interaction between dissolved inorganic $\mathrm{N}$ in the water column and the stream benthos resulting in increased $\mathrm{N}$ transport downstream. The consistent invariance across different

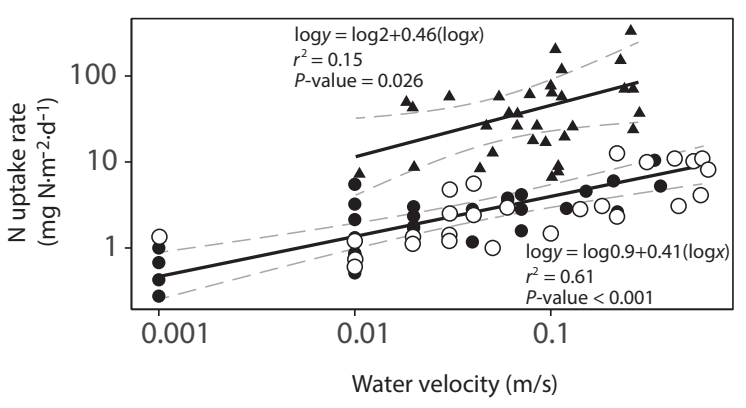

FIG. 6. Log-log relationship between water velocity and N uptake rates by epilithon (solid and open circles; data from Fuirosos stream), and by whole-reach $\mathrm{NH}_{4}^{+}$and $\mathrm{NO}_{3}^{-}$uptake rate estimates (triangles) from 32 different pristine streams across the United States (Peterson et al. 2001, Mulholland et al. 2008). Dashed bands represent $95 \%$ confidence regions. ANCOVA analysis with scale (microhabitat in our study and whole reach in 32 independent streams) as a main factor and water velocity as a covariate was used to validate the absence of significant differences between the two slopes $P=0.716$. 
spatial scales of the slope in the velocity-uptake relationship suggests that increases in water velocity seem to stimulate $\mathrm{N}$ uptake in a similar way at both low and high levels of stream organization. Therefore, $\mathrm{N}$ uptake stimulation by increases in water velocity may partially counter the effect of increased $\mathrm{N}$ transport and could explain in part why doubling stream water velocity does not simply double $\mathrm{N}$ transport downstream $\left(\log \left[\mathrm{NH}_{4}^{+}\right.\right.$ $\left.-S_{\mathrm{w}}\right]=0.71 \log [Q]+0.78$ in Peterson et al. [2001]). However, the nonlinear relationship between velocity and uptake also indicated a transition across domains of flow velocity. Small changes in water velocity within the low-velocity domain $(0.01-0.2 \mathrm{~m} / \mathrm{s}$, for the velocity range observed in this study) produced large increases in epilithon $\mathrm{N}$ uptake rate, while similar changes within the high-velocity domain $(0.2-0.6 \mathrm{~m} / \mathrm{s})$ resulted in much lower increases of epilithon $\mathrm{N}$ uptake rate. Thus, it is likely to believe that $\mathrm{N}$ uptake stimulation by water velocity at the reach scale may be only efficient to a certain magnitude of flow velocity.

\section{Implications for scaling up small-scale heterogeneity in microbial $N$ uptake}

Interactions between hydraulics and microbial $\mathrm{N}$ uptake at microhabitat scale revealed some caveats related to how small-scale heterogeneity in microbial $\mathrm{N}$ uptake is scaled up to the ecosystem level. Typically, the contribution of microbial compartments to whole-reach $\mathrm{N}$ uptake is quantified by averaging patch-specific data measured at several locations along the study reach (i.e., sample size typically equals $7-10$ replicates), and thus assuming that patch-specific $\mathrm{N}$ uptake rates are normally distributed along the reach. Our study reveals that microbial $\mathrm{N}$ uptake rates at the microhabitat level are rather not normally distributed within the stream bed, with the presence of highly active, low abundant microhabitat patches (i.e., hot spots). This is contrary to conventional wisdom in stream ecology. The presence or absence of normality in the spatial variation of microbial $\mathrm{N}$ uptake should have implications on how this variability is filtered when averaging per habitats or within reaches. For instance, when small-scale heterogeneity in microbial $\mathrm{N}$ uptake followed a more normal distribution (e.g., FBOM at the open reach), we observed a significant correlation between reach-scale $\mathrm{NH}_{4}^{+}$uptake measured from the ${ }^{15} \mathrm{~N}-\mathrm{NH}_{4}^{+}$decay in the water column and scaled up $\mathrm{NH}_{4}^{+}$uptake rates from FBOM and from both microbial compartments combined. However, in all other cases, our results demonstrated that when patch-specific $\mathrm{N}$ uptake rates were not normally distributed at smaller scales, drastic losses of spatial variation occurred when averaging at habitat and whole-reach scales with a high probability of not capturing those hot spots of microbial $\mathrm{N}$ uptake (Appendix S3). The use of median patch-specific $\mathrm{N}$ uptake rates instead of the commonly used mean values did improve our capacity to scale up rates measured at smaller scales, but not substantially. This suggests the importance of characterizing the spatial distribution of microhabitats and habitats to increase our capacity to scale up biogeochemical processes in heterogeneous systems like streams. This effort will likely require the use of geographic information systems that allow proper mapping and spatially explicit quantification of small-scale heterogeneity in stream $\mathrm{N}$ uptake. In this study, we demonstrated the presence of notable heterogeneity in microbial $\mathrm{N}$ uptake at smaller scales and discussed how it may generate important contributions to larger scales. However, more research is needed to properly determine the patch distribution characterizing this heterogeneity to fully understand how emergent properties from small spatial scales can contribute to shape patterns in stream $\mathrm{N}$ uptake at the ecosystem level.

\section{ACKNOWLEDGMENTS}

The authors would like to thank E. Martin, C. Romero, S. Soley, R. González-Pinzón, and Gacia's family for their field assistance, and R. Ventosa from the CEAB-CSIC Nutrient Analysis Service for analytical work. We would also thank two anonymous reviewers for constructive comments on the manuscript. Financial support was provided by the Spanish Ministry of Science and Innovation through the ISONEF (ref: CGL200805504-C02-02/BOS) and MED_FORESTREAM (ref:CGL201130590-C02-02) projects. M. Peipoch and E. Bastias were granted by two FPI PhD fellowships from the Spanish Ministry of Science and Innovation through the ISONEF and MEDFORESTREAM projects, respectively. M. Ribot was supported by a technical training contract also associated to ISONEF project.

\section{Literature Cited}

APHA. 1995. Standard methods for the examination of water and wastewater, Nineteenth edition. American Publishers Health Association, Washington, D.C., USA.

Artigas, J., A. M. Romaní, A. Gaudes, I. Muñoz, and S. Sabater. 2008. Organic matter availability structures microbial biomass and activity in a Mediterranean stream. Freshwater biology 10:1111-12.

Baker, M. A., G. de Guzman, and J. D. Ostermiller. 2009. Differences in nitrate uptake among benthic algal assemblages in a mountain stream. Journal of the North American Benthological Society 28:24-33.

Battin, T. J., L. A. Kaplan, J. D. Newbold, X. H. Cheng, and C. Hansen. 2003. Effects of current velocity on the nascent architecture of stream microbial biofilms. Applied and Environmental Microbiology 69:5443-5452.

Besemer, K., G. Singer, R. Limberger, A.-K. Chlup, G. Hochedlinger, I. Hoedl, C. Baranyi, and T. J. Battin. 2007. Biophysical controls on community succession in stream biofilms. Applied and Environmental Microbiology 73:4966-4974.

Besemer, K., G. Singer, I. Hodl, and T. J. Battin. 2009. Bacterial community composition of stream biofilms in spatially variable-flow environments. Applied and Environmental Microbiology 75:7189-7195.

Bonin, H. L., R. P. Griffiths, and B. A. Caldwell. 2000. Nutrient and microbiological characteristics of fine benthic organic matter in mountain streams. Journal of the North American Benthological Society 19:235-249. 
Butturini, A., and F. Sabater. 1998. Ammonium and phosphate retention in a Mediterranean stream: hydrological versus temperature control. Canadian Journal of Fisheries and Aquatic Sciences 55:1938-1945.

Butturini, A., M. Alvarez, S. Bernal, E. Vazquez, and F. Sabater. 2008. Diversity and temporal sequences of forms of DOC and $\mathrm{NO}_{3}{ }^{-}$discharge responses in an intermittent stream: predictable or random succession? Journal of Geophysical ResearchBiogeosciences 113:10.

Cardinale, B. J., M. A. Palmer, C. M. Swan, S. Brooks, and N. L. Poff. 2002. The influence of substrate heterogeneity on biofilm metabolism in a stream ecosystem. Ecology $83: 412-422$

Dodds, W. K., et al. 2000. Quantification of the nitrogen cycle in a prairie stream. Ecosystems 3:574-589.

Dubois, M., K. A. Gilles, J. K. Hamilton, P. A. Rebers, and F. Smith. 1956. Colorimetric method for determination of sugars and related substances. Analytical Chemistry 28:350-356.

Findlay, S., et al. 2002. A cross-system comparison of bacterial and fungal biomass in detritus pools of headwater streams. Microbial Ecology 43:55-66.

Finlay, J. C., M. E. Power, and G. Cabana. 1999. Effects of water velocity on algal carbon isotope ratios: implications for river food web studies. Limnology and Oceanography 44:1198-1203.

Fisher, S. G., N. B. Grimm, E. Marti, and R. Gomez. 1998. Hierarchy, spatial configuration, and nutrient cycling in a desert stream. Australian Journal of Ecology 23:41-52.

Frissell, C. A., W. J. Liss, C. E. Warren, and M. D. Hurley. 1986. A hierarchical framework for stream habitat classification-viewing streams in a watershed context. Environmental Management 10:199-214.

Gantzer, C. J., B. E. Rittmann, and E. E. Herricks. 1988. Masstransport to streambed biofilms. Water Research 22:709-722.

Gessner, M. O., and E. Chauvet. 1994. Importance of stream microfungi in controlling breakdown rates of leaf-litter. Ecology 75:1807-1817.

Grimm, N. B. 1987. Nitrogen dynamics during succession in a desert stream. Ecology 68:1157-1170.

Harms, T. K., and N. B. Grimm. 2008. Hot spots and hot moments of carbon and nitrogen dynamics in a semiarid riparian zone. Journal of Geophysical Research-Biogeosciences 113:G01020.

Holmes, R. M., J. W. McClelland, D. M. Sigman, B. Fry, and B. J. Peterson. 1998. Measuring N-15- $\mathrm{NH}_{4}^{+}$in marine, estuarine and fresh waters: an adaptation of the ammonia diffusion method for samples with low ammonium concentrations. Marine Chemistry 60:235-243.

Kemp, M. J., and W. K. Dodds. 2001. Centimeter-scale patterns in dissolved oxygen and nitrification rates in a prairie stream. Journal of the North American Benthological Society 20:347-357.

King, R. S., C. J. Richardson, D. L. Urban, and E. A. Romanowicz. 2004. Spatial dependency of vegetationenvironment linkages in an anthropogenically influenced wetland ecosystem. Ecosystems 7:75-97.

Knapp, C. W., W. K. Dodds, K. C. Wilson, J. M. O'Brien, and D. W. Graham. 2009. Spatial heterogeneity of denitrification genes in a highly homogenous urban stream. Environmental Science \& Technology 43:4273-4279.

Levin, S. A. 1992. The problem of pattern and scale in ecology. Ecology 73:1943-1967.

Lock, M. A. 1993. Attached microbial communities in rivers. Pages 113-138 in T. E. Ford, editor. Aquatic microbiology: an ecological approach. Blackwell Scientific Publications, Osney Mead, Oxford, UK.
Marti, E., and F. Sabater. 1996. High variability in temporal and spatial nutrient retention in Mediterranean streams. Ecology 77:854-869.

McClain, M. E., et al. 2003. Biogeochemical hot spots and hot moments at the interface of terrestrial and aquatic ecosystems. Ecosystems 6:301-312.

Merriam, J. L., W. H. McDowell, J. L. Tank, W. M. Wollheim, C. L. Crenshaw, and S. L. Johnson. 2002. Characterizing nitrogen dynamics, retention and transport in a tropical rainforest stream using an in situ N-15 addition. Freshwater Biology 47:143-160.

Mulholland, P. J., J. L. Tank, D. M. Sanzone, W. M. Wollheim, B. J. Peterson, J. R. Webster, and J. L. Meyer. 2000. Nitrogen cycling in a forest stream determined by a N-15 tracer addition. Ecological Monographs 70:471-493.

Mulholland, P. J., et al. 2008. Stream denitrification across biomes and its response to anthropogenic nitrate loading. Nature 452:202-205.

Newbold, J. D., J. W. Elwood, R. V. Oneill, and W. Vanwinkle. 1981. Measuring nutrient spiralling in streams. Canadian Journal of Fisheries and Aquatic Sciences 38:860-863.

O'Brien, J. M., W. K. Dodds, K. C. Wilson, J. N. Murdock, and J. Eichmiller. 2007. The saturation of $\mathrm{N}$ cycling in Central Plains streams: N-15 experiments across a broad gradient of nitrate concentrations. Biogeochemistry 84:31-49.

O'Neill, R. V., D. L. Deangelis, J. B. Waide, and G. E. Allen. 1986. A hierarchical concept of ecosystems, First edition. Princeton University Press, Princeton, New Jersey, USA.

Peters, D. P. C., B. T. Bestelmeyer, and M. G. Turner. 2007. Cross-scale interactions and changing pattern-process relationships: consequences for system dynamics. Ecosystems 10:790-796.

Peterson, B. J., et al. 2001. Control of nitrogen export from watersheds by headwater streams. Science 292:86-90.

Pinheiro J, Bates D, DebRoy S, Sarkar D and R Core Team 2015. nlme: Linear and Nonlinear Mixed Effects Models_. R package version 3:1-122. http://CRAN.R-project.org/ package $=$ nlme $>$.

Poole, G. C. 2002. Fluvial landscape ecology: addressing uniqueness within the river discontinuum. Freshwater Biology 47:641-660.

Proia, L., A. M. Romani, and S. Sabater. 2012. Nutrients and light effects on stream biofilms: a combined assessment with CLSM, structural and functional parameters. Hydrobiologia 695:281-291.

R Development Core Team. 2013. R 3.0.0. R Foundation for Statistical Computing, Vienna, Austria. http://www.Rproject.org/

Rier, S. T., and R. J. Stevenson. 2002. Effects of light, dissolved organic carbon, and inorganic nutrients on the relationship between algae and heterotrophic bacteria in stream periphyton. Hydrobiologia 489:179-184.

Romani, A. M., and S. Sabater. 1999. Effect of primary producers on the heterotrophic metabolism of a stream biofilm. Freshwater Biology 41:729-736.

Romani, A. M., K. Fund, J. Artigas, T. Schwartz, S. Sabater, and U. Obst. 2008. Relevance of polymeric matrix enzymes during biofilm formation. Microbial Ecology 56:427-436.

Sabater, F., A. Butturini, E. Marti, I. Munoz, A. Romani, J. Wray, and S. Sabater. 2000. Effects of riparian vegetation removal on nutrient retention in a Mediterranean stream. Journal of the North American Benthological Society 19:609-620.

Sakamaki, T., and J. S. Richardson. 2013. Nonlinear variation of stream-forest linkage along a stream-size gradient: an assessment using biogeochemical proxies of in-stream fine 
particulate organic matter. Journal of Applied Ecology 50:1019-1027.

Sheath, R. G., and K. M. Cole. 1992. Biogeography of stream macroalgae in North America. Journal of Phycology 28:448-460.

Sigman, D. M., M. A. Altabet, R. Michener, D. C. McCorkle, B. Fry, and R. M. Holmes. 1997. Natural abundance-level measurement of the nitrogen isotopic composition of oceanic nitrate: an adaptation of the ammonia diffusion method. Marine Chemistry 57:227-242.

Simon, K. S., D. K. Niyogi, R. D. Frew, and C. R. Townsend 2007. Nitrogen dynamics in grassland streams along a gradient of agricultural development. Limnology and Oceanography 52:1246-1257.

Singer, G., K. Besemer, P. Schmitt-Kopplin, I. Hodl, and T. J. Battin. 2010. Physical heterogeneity increases biofilm resource use and its molecular diversity in stream mesocosms. PLoS ONE 5:e9988.

Sponseller, R. A., and S. G. Fisher. 2006. Drainage size, stream intermittency, and ecosystem function in a Sonoran Desert landscape. Ecosystems 9:344-356.

Tank, J. L., J. L. Meyer, D. M. Sanzone, P. J. Mulholland, J. R. Webster, B. J. Peterson, W. M. Wollheim, and N. E. Leonard. 2000. Analysis of nitrogen cycling in a forest stream during autumn using a N-15-tracer addition. Limnology and Oceanography 45:1013-1029.

Thompson, J. N., et al. 2001. Frontiers of ecology. BioScience $51: 15-24$.

Trudeau, V., and J. B. Rasmussen. 2003. The effect of water velocity on stable carbon and nitrogen isotope signatures of periphyton. Limnology and Oceanography 48:2194-2199.

Turner, M. G., and F. S. Chapin. 2005. Causes and consequences of spatial heterogeneity in ecosystem function. Pages
9-30 in G. M. Lovett, C. G. Jones, M. G. Turner, and K. C. Weathers, editors. Ecosystem function in heterogeneous landscapes. Springer, New York, New York, USA.

Valett, H. M., J. A. Morrice, C. N. Dahm, and M. E. Campana. 1996. Parent lithology, surface-groundwater exchange, and nitrate retention in headwater streams. Limnology and Oceanography 41:333-345.

Valett, H. M., S. A. Thomas, P. J. Mulholland, J. R. Webster, C. N. Dahm, C. S. Fellows, C. L. Crenshaw, and C. G. Peterson. 2008. Endogenous and exogenous control of ecosystem function: $\mathrm{N}$ cycling in headwater streams. Ecology 89:3515-3527.

Vazquez, E., et al. 2013. Fourteen years of hydro-biogeochemical monitoring in a Mediterranean catchment. Die Bodenkultur 64:13-20.

von Schiller, D., E. Marti, and J. L. Riera. 2009. Nitrate retention and removal in Mediterranean streams bordered by contrasting land uses: a N-15 tracer study. Biogeosciences 6:181-196.

Ward, J. V. 1989. The 4-dimensional nature of lotic ecosystems. Journal of the North American Benthological Society $8: 2-8$.

Webster, J. R., and H. M. Valett. 2006. Solute dynamics. Pages 169-186 in F. R. Hauer, and G. A. Lamberti, editors. Methods in stream ecology. Academic Press, Irvine, California, USA.

Webster, J. R., et al. 2003. Factors affecting ammonium uptake in streams - an inter-biome perspective. Freshwater Biology 48:1329-1352.

Ylla, I., I. Sanpera-Calbet, E. Vazquez, A. M. Romani, I. Munoz, A. Butturini, and S. Sabater. 2010. Organic matter availability during pre- and post-drought periods in a Mediterranean stream. Hydrobiologia 657:217-232.

\section{SUPPORTING INFORMATION}

Additional supporting information may be found in the online version of this article at http://onlinelibrary.wiley.com/ doi/10.1890/15-1210.1/suppinfo 